\title{
Radioactive Air Emissions Notice of Construction Portable/Temporary Radioactive Air Emission Units
}

Date Published

August 1996

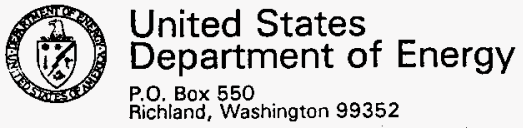

Approved for Public Release 
THIS … M.TENTIONALLY UINK 


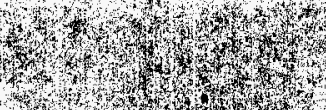

1.t.

3
3

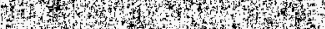

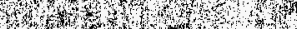

m.t.

T.7.

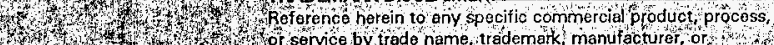

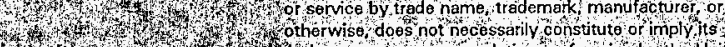

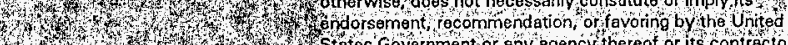

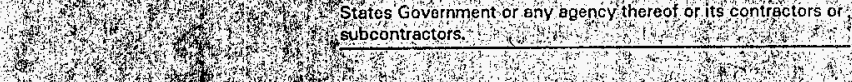

4.

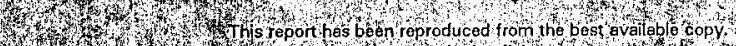

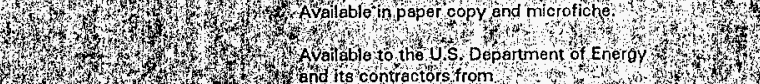

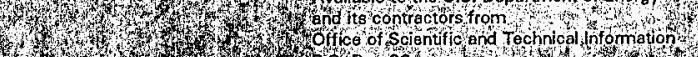

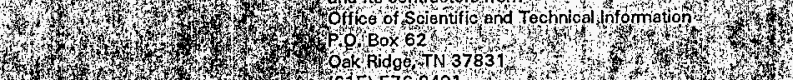

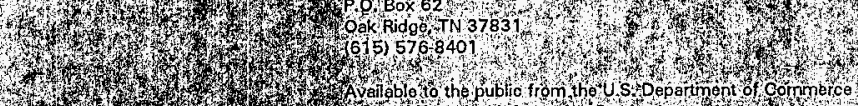

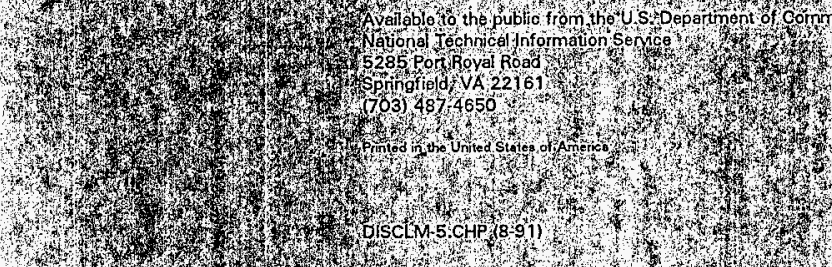

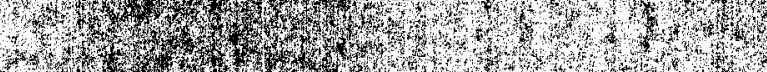

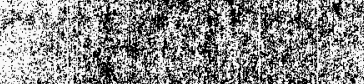

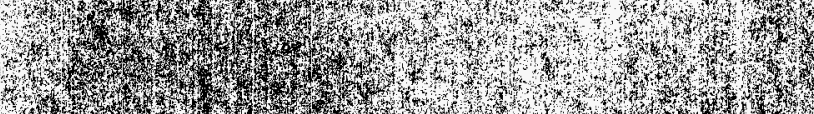

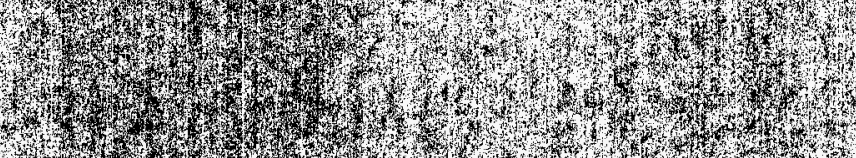

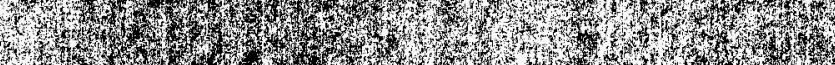

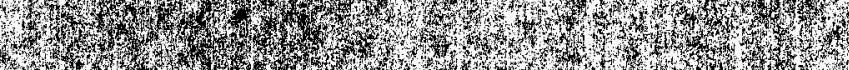

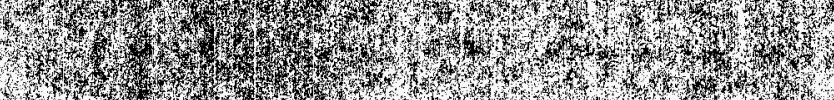

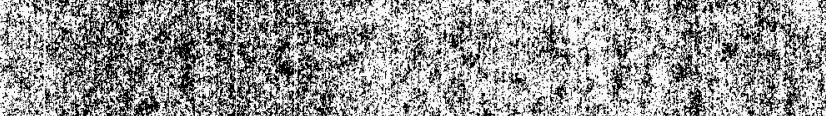

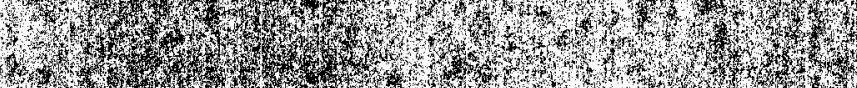

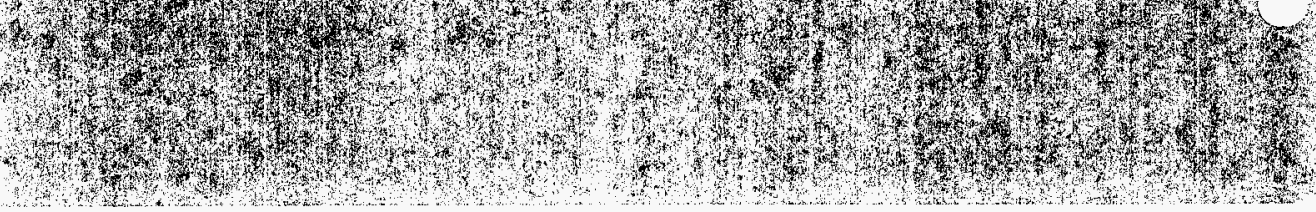


THIS PAGE INTENTJONALLY LETT BLANK 


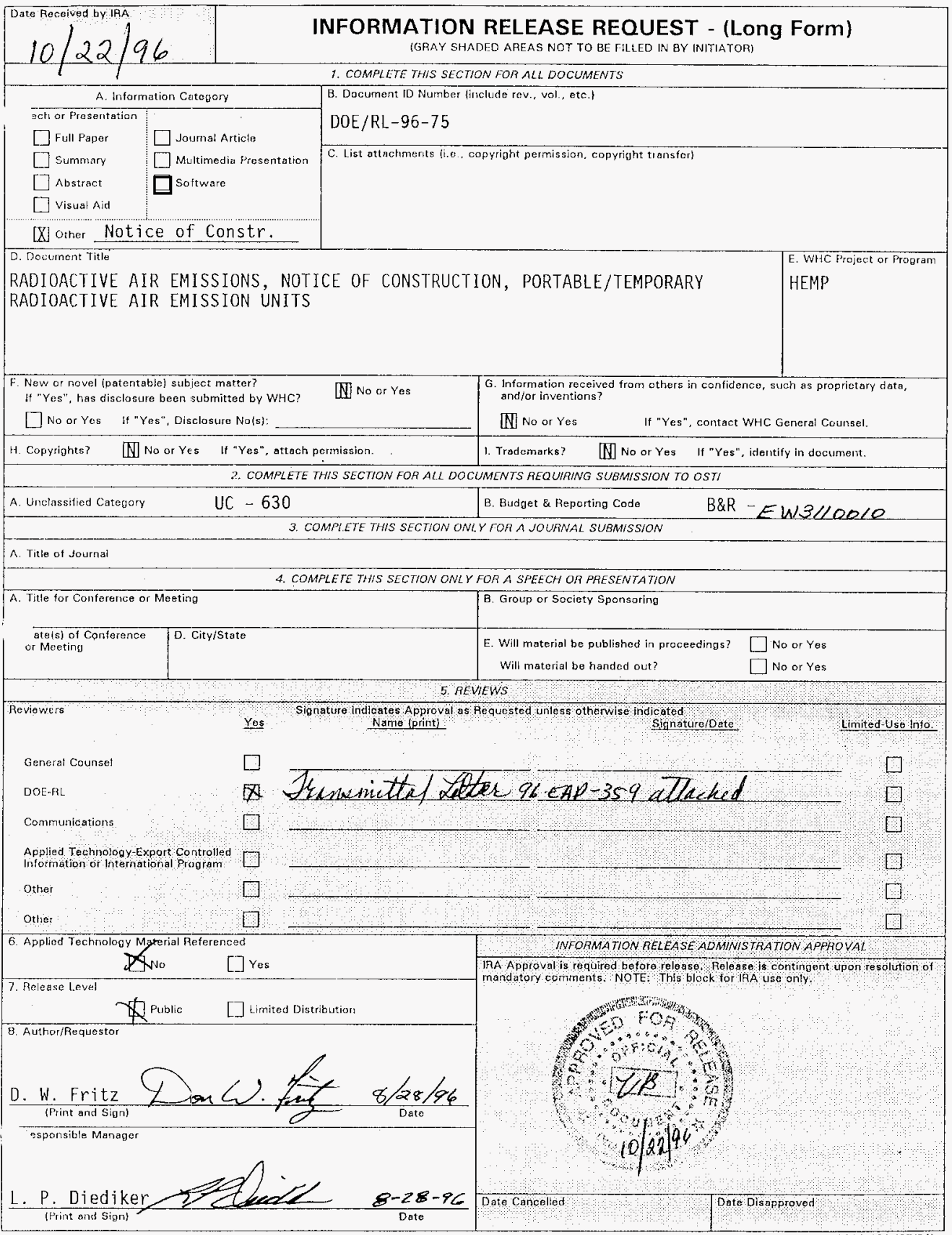


THIS FAT INTINTI NALIY LEF'' 'BLANK 
D0E/RL-96-75

Document ID Number

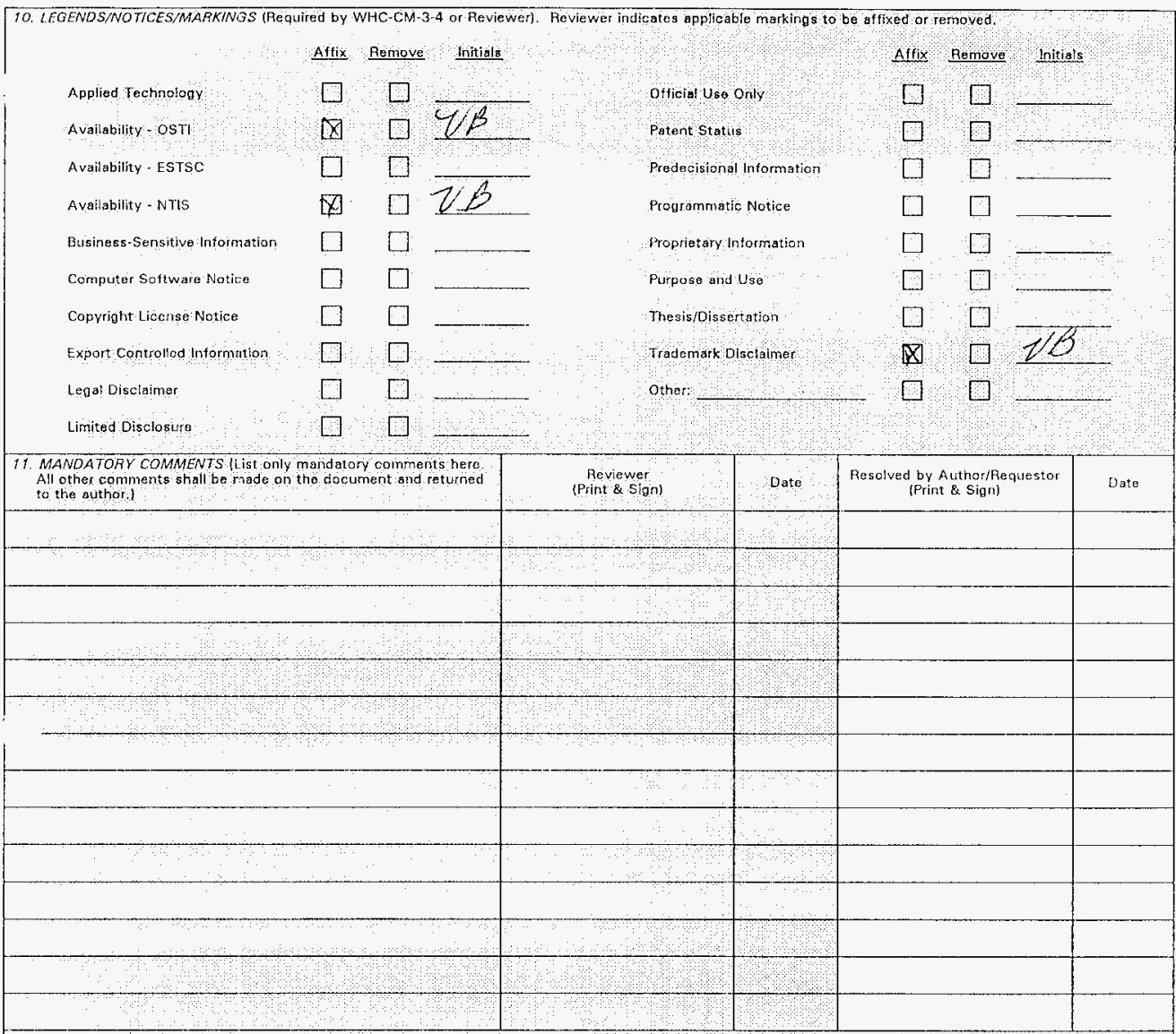

12. AODITONALINFOIMATIONICOMMINTS: 


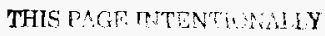

I. W : MNR 


\section{CONTENTS}

TERMS .......................

METRIC CONVERSION CHART ................. vi

1.0 INTRODUCTION .................... 1

2.0 FACILITY LOCATION . . . . . . . . . . . . . . 2

3.0 RESPONSIBLE MANAGER $($ Requirement 2$) \ldots \ldots \ldots 2$

4.0 TYPE OF PROPOSED ACTION (Requirement 3 ) ............. 2

5.0 STATE ENVIRONMENTAL POLICY ACT (Requirement 4) . . . . . . . . 2

6.0 PROCESS DESCRIPTION (Requir rement 5 and 7 ) . . . . . . . . . 3

7.0 ANNUAL POSSESSION QUANTITY AND PHYSICAL FORM

(Requi rennents 8, 10, 11, AND 12) . . . . . . . . . . . . 3

8.0 CONTROL SYSTEM (Requirement 6$) \ldots \ldots \ldots 5$

9.0 MONITORING SYSTEM (Requirenent 9 ) ............ 6

10.0 RELEASE RATES (Requirenent 13 ) . . . . . . . . . . . 7

10.1 UNABATED EMISSIONS .................. 7

10.2 ABATED EMISSIONS . . . . . . . . . . . . . . . 8

11.0 OFFSITE IMPACT (Requirements 14 and 15$) \ldots \ldots . \ldots 9$

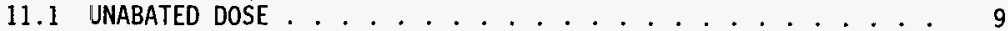

11.2 ABATED DOSE . . . . . . . . . . . . . . . . 10

12.0 FACILITY LIFETIME (Requirement 17 ) . . . . . . . . . . 11

13.0 TECHNOLOGY STANDARDS $($ Requirement 18 ) ............ 11

14.0 DISCUSSION OF BEST AVAILABLE RADIONUCLIDE CONTROL TECHNOLOGY . . . 12

15.0 REFERENCES . . . . . . . . . . . . . 12 
1

2

3

4

5

6

8

9

10

11

12

APPENDICES

A SCHEMATICS AND DRAWINGS "TYPICAL SAMPLE PREPARATION" UNIT . . APP A-i B RADIOACTIVE HANDLING LIMITS ............. APP B-i

C SAMPLE DATA USED FOR TYPE II AND III UNITS ........ APP $C-i$

D PORTABLE/TEMPORARY RADIONUCLIDE AIRBORNE EMISSION UNIT LISTINGS . . . . . . . . . . . . . . . . . . APP D $D$. . .

E EXAMPLE OF A LOG SHEET AND EXAMPLE CALCULATIONS TO DETERMINE MAXIMUM EXPECTED ANNUAL EMISSIONS ............ APP E-i

\section{TABLES}

1. Facility Inventory .................. 5

2. Unabated Emissions ................... . . 8

3. Abated Emissions .................. . . . 9

4. Unabated Dose ...................... 10

5. Abated Dose . . . . . . . . . . . . . . . . . 11

6. Control Technology Standards .............. 12 


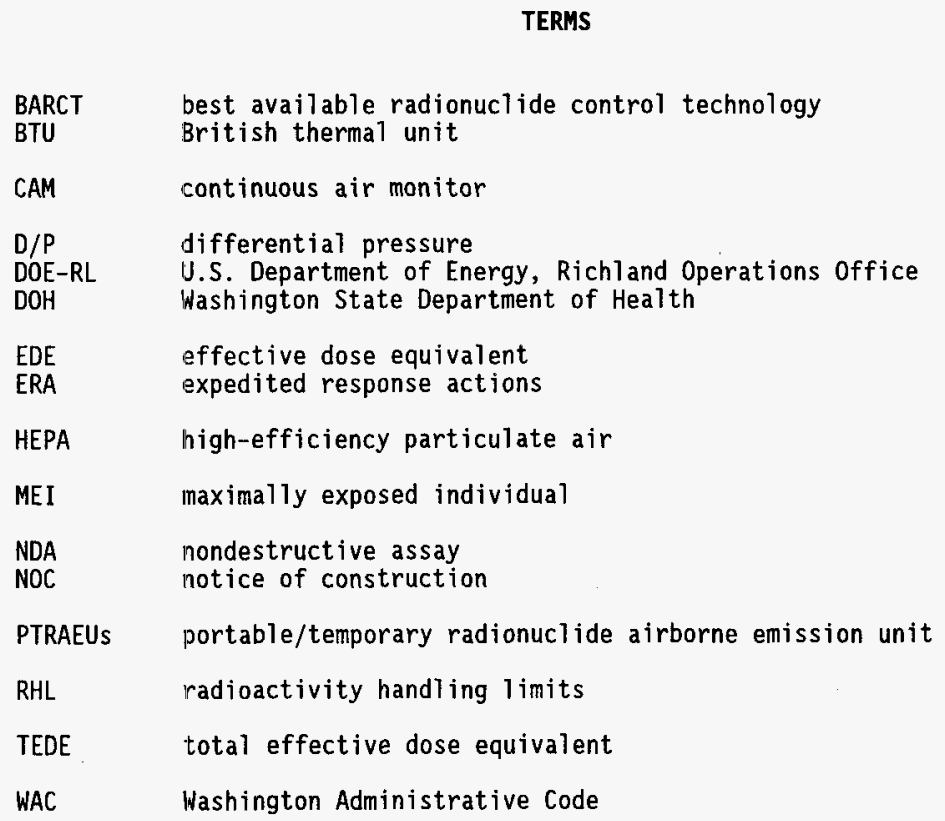


,

3

4

\section{5}

6

7

8

9

10

12

13

\section{METRIC CONVERSION CHART}

Into metric units

Out of metric units

\begin{tabular}{|c|c|c|c|c|c|}
\hline If you know & $\begin{array}{c}\text { Muitiply } \\
\text { by }\end{array}$ & To get & If you know & $\begin{array}{c}\text { Multiply } \\
\text { by }\end{array}$ & To get \\
\hline \multicolumn{3}{|c|}{ Length } & \multicolumn{3}{|c|}{ Length } \\
\hline inches & 25.40 & millimeters & millimeters & 0.0393 & inches \\
\hline inches & 2.54 & centimeters & cent imeters & 0.393 & inches \\
\hline feet & 0.3048 & meters & meters & 3.2808 & feet \\
\hline yards & 0.914 & meters & meters & 1.09 & yards \\
\hline miles & 1.609 & kilometers & kilometers & 0.62 & miles \\
\hline \multicolumn{3}{|c|}{ Area } & \multicolumn{3}{|c|}{ Area } \\
\hline $\begin{array}{l}\text { square } \\
\text { inches }\end{array}$ & 6.4516 & $\begin{array}{l}\text { square } \\
\text { centimeters }\end{array}$ & $\begin{array}{l}\text { square } \\
\text { cent imeters }\end{array}$ & 0.155 & $\begin{array}{l}\text { square } \\
\text { inches }\end{array}$ \\
\hline square feet & 0.092 & $\begin{array}{l}\text { square } \\
\text { meters }\end{array}$ & $\begin{array}{l}\text { square } \\
\text { meters }\end{array}$ & 10.7639 & $\begin{array}{l}\text { square } \\
\text { feet }\end{array}$ \\
\hline $\begin{array}{l}\text { square } \\
\text { yards }\end{array}$ & 0.836 & $\begin{array}{l}\text { square } \\
\text { meters }\end{array}$ & $\begin{array}{l}\text { square } \\
\text { meters }\end{array}$ & 1.20 & $\begin{array}{l}\text { square } \\
\text { yards }\end{array}$ \\
\hline $\begin{array}{l}\text { square } \\
\text { miles }\end{array}$ & 2.59 & $\begin{array}{l}\text { square } \\
\text { kilometers }\end{array}$ & $\begin{array}{l}\text { square } \\
\text { kilometers }\end{array}$ & 0.39 & $\begin{array}{l}\text { square } \\
\text { miles }\end{array}$ \\
\hline acres & 0.404 & hectares & hectares & 2.471 & acres \\
\hline \multicolumn{3}{|c|}{ Mass (weight) } & \multicolumn{3}{|c|}{ Mass (weight) } \\
\hline ounces & 28.35 & grams & grams & 0.0352 & ounces \\
\hline pounds & 0.453 & kilograms & kilograms & 2.2046 & pounds \\
\hline short ton & 0.907 & metric ton & metric ton & 1.10 & short ton \\
\hline \multicolumn{3}{|c|}{ Vol ume } & \multicolumn{3}{|c|}{ Volume } \\
\hline $\begin{array}{l}\text { fluid } \\
\text { ounces }\end{array}$ & 29.57 & milliliters & milliliters & 0.03 & $\begin{array}{l}\text { fluid } \\
\text { ounces }\end{array}$ \\
\hline quarts & 0.95 & Titers & liters & 1.057 & quarts \\
\hline gallons & 3.79 & Titers & 1iters & 0.26 & gallons \\
\hline cubic feet & 0.03 & $\begin{array}{l}\text { cubic } \\
\text { meters }\end{array}$ & $\begin{array}{l}\text { cubic } \\
\text { meters }\end{array}$ & 35.3147 & cubic feet \\
\hline cubic yards & 0.76456 & $\begin{array}{l}\text { cubic } \\
\text { meters }\end{array}$ & $\begin{array}{l}\text { cubic } \\
\text { meters }\end{array}$ & 1.308 & $\begin{array}{l}\text { cubic } \\
\text { yards }\end{array}$ \\
\hline \multicolumn{3}{|c|}{ Temperature } & \multicolumn{3}{|c|}{ Temperature } \\
\hline Fahrenheit & $\begin{array}{l}\text { subtract } \\
32 \text { then } \\
\text { multiply } \\
\text { by } 5 / 9 \text { ths }\end{array}$ & Celsius & Celsius & $\begin{array}{l}\text { multiply } \\
\text { by } \\
9 / 5 \text { ths, } \\
\text { then add } \\
32\end{array}$ & Fahrenheit \\
\hline \multicolumn{3}{|c|}{ Force } & \multicolumn{3}{|c|}{ Force } \\
\hline $\begin{array}{l}\text { pounds per } \\
\text { square inch }\end{array}$ & 6.895 & kilopascals & kilopascals & $\begin{array}{l}1.4504 \times \\
10^{-4}\end{array}$ & $\begin{array}{l}\text { pounds per } \\
\text { square } \\
\text { inch }\end{array}$ \\
\hline
\end{tabular}

Source: Engineering Unit Conversions, M. R. Lindeburg, PE., Second Ed., 1990, Professional Publications, Inc., Belmont, California. 
DOE/RL-96-75, Rev. 0

$08 / 96$

\section{RADIOACTIVE AIR EMISSIONS \\ NOTICE OF CONSTRUCTION \\ PORTABLE/TEMPORARY RADIOACTIVE AIR EMISSION UNITS}

\subsection{INTRODUCTION}

This notice of construction (NOC) requests a categorical approval for construction and operation of three types of portable/temporary radionuclide airborne emission units (PTRAEUs). These three types are portable ventilation-filter systems (Type I), mobile sample preparation facilities (Type II), and mobile sample screening and analys is facilities (Type III). Approval of the NOC application is intended to allow construction and operation of the three types of PTRAEUs without prior project-specific approval.

Environmental cleanup efforts on the Hanford Site often require the use of PTRAEUs. The PTRAEUs support site characterization activities, expedited response actions (ERAs), sampling and monitoring activities, and other routine activities. The PTRAEUs operate at various locations around the Hanford Site.

Radiation Air Emissions Program, Washington Administrative Code (WAC) $246-247$, requires that the Washington State Department of Health (DOH) be notified before construction of any new emission that would release airborne radioactivity. The $\mathrm{DOH}$ also must receive notification before any modification of an existing source. This includes changes in the source term or replacement of emission control equipment, which significantly might contribute to the offsite maximum dose from a licensed facility.

During site characterization activities, ERAs, sampling and monitoring activities, and other routine activities, the PTRAEUs might require startup immediately. The notification period hampers efforts to complete such activities in an effective and timely manner. Additionally, notification is to be submitted to the DOH when the PTRAEUs are turned off. The U.S. Department of Energy, Richland Operations Office (DOE-RL) potentially could generate several notifications monthly. The DOH would be required to review and provide approval on each NOC as well as review the notices of discontinued sources. The $\mathrm{DOH}$ regulation also allows facilities the opportunity to request a single categorical license that identifies 7 imits and conditions of operations for similar multipurpose temporary and/or portable emission units.

The DOE-RL will submit annually to the DOH a report summarizing the log books maintained on the individual PTRAEUs. The report will supply information needed to maintain oversight of the operations of PTRAEUs on the Hanford Site.

The NOC includes a general description of the three types of PTRAEUs, tracking mechanisms, emissions control systems, and radioactivity handling limits (RHLs) for the PTRAEUs. The NOC is based on hypothetical data to demonstrate how emission estimates could be calculated. Tracking will be 
1 performed and monitoring will be conducted for compliance with both federal 2 and state regulations. Type I units will use a single isotope based on a 3 calculated RHL (source term) to determine emissions, dose, and monitoring 4 requirements. Type II and III units will use field data and process knowledge 5 to determine emissions, dose, and monitoring requirements.

New PTRAEUs that conform to any of the three types of PTRAEUs described in this application will be added to the next annual report after the units are placed in service. Any unit fitting into a category will be evaluated for its applicability to this application before being placed into service.

New PTRAEUs, which do not conform to any of the three types of PTRAEUs described in this application, will require approval on an individual basis by the $\mathrm{DOH}$ before startup.

\title{
2.0 FACILITY LOCATION
}

U.S. Department of Energy, Richland Operations Office Hanford Site

Richland, Washington 99352

The PTRAEUs could be located at any facility located on the Hanford Site. These units are portable and are used in various locations as needed.

\subsection{RESPONSIBLE MANAGER (Requirement 2)}

\author{
Mr. J. E. Rasmussen, Division Director \\ Office of Environmental Assurance, \\ Policy, and Permits \\ U.S. Department of Energy, Richland Operations Office \\ P.0. Box 550 \\ Richland, Washington 99352
}

\subsection{TYPE OF PROPOSED ACTION (Requirement 3)}

This proposed action serves as a categorical permit for existing and future PTRAEIJs and modification of similar sources located and operated on the Hanford Site.

\subsection{STATE ENVIRONMENTAL POLICY ACT (Requirement 4)}

The use of PTRAEUs is categorically exempt from the State Environmental Policy Act of 1971 process. 
Type I PTRAEUs are portable ventilation-filter units. Type II PTRAEUs are mobile sample preparation units. Type III PTRAEUs are mobile screening and analysis units. Each type of PTRAEU is described in the following paragraphs.

Most of the PTRAEUs are portable ventilation-filter units (Type I) with a capacity from approximately 50 to 2,000+ cubic feet per minute exhaust flow rate. The portable ventilation-filter units control radionuclide emissions by providing filtered ventilation on sites where work activities potentially could disturb areas with radioactive contamination. Type I units that are vacuums are listed to be used as ventilation units. If the vacuum is used in any other manner/process, the $\mathrm{DOH}$ must approve its use under separate application before the activity commences.

Mobile sample preparation units (Type II) decrease the chance of unintentional cross-contamination of samples and enhance personnel radiological safety. The sample preparation units enable technicians to remove material from core barrels, homogenize the material, and fill prescribed sample containers for onsite and offsite analysis. In enclosed, self-contained sample preparation units, radiological exposure and interference from environmental conditions (i.e., wind, precipitation, and exhaust fumes) are minimized. Examples of a typical sample preparation unit and other diagrams are presented in Appendix $A$.

Mobile sample screening and analysis units (Type III) provide preliminary screening of samples to determine potential problem areas at a site. The units also screen samples to identify those samples requiring further in-depth analysis. Screening samples decreases the number of samples transported for analysis. The fast turnaround analysis time can provide results for a field situation requiring expeditious response.

The source of radionuclides handled by the mobile sample preparation facilities and mobile screening and analysis facilities is contaminated soils and/or liquids extracted from cribs, ditches, ponds, burial sites, and other such areas with surficial soil contamination. An additional source of radionuclides is the preparation of radioactive standards to be used for instrument calibration.

\subsection{ANNUAL POSSESSION QUANTITY AND PHYSICAL FORM (Requirements 8, 10, 11, AND 12)}

The facility inventory that a PTRAEU does or will handle varies from activity to activity. In many cases, the exact inventory is unknown at the beginning of the activity. To assist operators of the PTRAEUs to determine the requirements for compliance with federal and state regulations, RHLs were derived for each of the major areas where PTRAEUs could be operated. 
The RHLs were calculated for a daily use because many of the activities are of short duration. The second assumption in calculating the RHLs was that the 0.1 millirem per year criteria is used, as a beginning point and the source term that could be handled each day is back calculated. The RHLs and instructions for their use are found in Appendix B.

Table 1 lists the source term that the different types of units theoretically could handle. The RHLs (source term) were used to determine Type I facility inventory (per activity); sample data and process knowledge were used in determining Type II and III facility inventory (per activity).

The inventories for Type I units were derived by using the RHL for cesium-137 found in the 300 Area and handled 365 days per year by a single unit. The RHL for cesium-137 is $5.70 \mathrm{E}-01$ curies per day multiplied by 365 days, which equals the inventory listed in Table 1.

The inventories for Type II and III units were based on sample analysis (Appendix C) for cesium-137, strontium-90 and americium-241 and limited by the number of samples handled at each location during a year. Type II units could handle 100 samples and Type III units could handle 1,100 samples.

A11 inventories in Table 1 are based on hypothetical worst-case source terms that a portable unit could handle during any given activity and remain below 0.1 millirem per year unabated dose.

When a user determines the source term (e.g., facility inventory) for the activity, the user will take into consideration all radionuclides that potentiaily contribute 10 percent of the total effective dose equivalent (TEDE) to the maximum exposed individual (MEI).

For Type I units, the confinement method or structure is considered contiguous with the ventilation system. All source material at risk within confinement must be included in the emission estimates. This means that actively ventilating a high-level waste tank is different from a previously approved passive system that does not pull a negative pressure on the source term.

Additionally, if a portable unit is used inside or near an existing source whose facility stack is registered with the DOH and the activity emissions are vented through that stack, causing no net increase to the original potential to emit, the unit is not required to comply with this application. Under this condition the process that is performed routinely or a routine maintenance activity that is conducted, the source term for the facility does not increase. 
Table 1. Facility Inventory.

\begin{tabular}{||c|c|c|}
\hline Radionuclides & Physical form & $\begin{array}{c}\text { Annual possession quantity } \\
\text { (curies per year) }\end{array}$ \\
\hline \hline \multicolumn{3}{|c|}{ TYPE I UNIT } \\
\hline Cs-137 & Particulate/liquids \\
\hline \multicolumn{3}{|c|}{ TYPE II UNIT } \\
\hline Cs-137 & Particulate/liquids & $2.08 \mathrm{E}+2$ \\
\hline Sr-90 & Particulate/liquids & $3.6 \mathrm{E}+00$ \\
\hline Am-241 & Particulate/liquids & $6.6 \mathrm{E}+00$ \\
\hline \multicolumn{3}{|c|}{ TYPE III UNIT } \\
\hline Cs-137 & Particulate/liquids & $3.2 \mathrm{E}-03$ \\
\hline Sr-90 & Particulate/liquids & $7.26 \mathrm{E}+01$ \\
\hline Am-241 & Particulate/liquids & $2.42 \mathrm{E}-02$ \\
\hline
\end{tabular}

\subsection{CONTROL SYSTEM (Requirement 6)}

All portable ventilation filter units (Type I) are equipped with a high-efficiency particulate air (HEPA) filter. Some of the portable ventilation filter systems have an additional HEPA filter in series, a charcoal adsorber(s) or moisture separator(s).

The mobile sample preparation and mobile screening and analysis units (Type II and Type III) have an exhaust system consisting of a single-stage HEPA filter, followed by an activated charcoal adsorber. The activated charcoal adsorbers would abate any radioactive iodine released during operation of the PTRAEUs.

For new HEPA installations, the systems are field tested, requiring an aerosol test/efficiency test or equivalent pass/fail criteria of 99.95 percent.

The PTRAEU filtration systems are tested whenever the system is modified and/or opened or annually, whichever occurs first. Type II and III units are not affected by a move to another location, unless the glovebox/HEPA control system physically is removed from the trailer or if the control system is opened. If the entire laboratory is relocated, there is no need for testing; however, if the inside equipment is removed from one trailer to another, aerosol testing/efficiency testing would be required. Certification of testing is verified by affixing a label on the unit that indicates who performed the test, the test date, and if the unit passed the test. The label should be placed in a conspicuous location on the unit. 
At any given location, the length of operation of portable ventilation-filter systems typically will span 4 weeks to 6 months. Mobile sample preparation and screening and analysis facilities can operate for extended periods on projects relating to site characterization (e.g., 1 to 2 years).

Appendix D contains a table of PTRAEUs used on the Hanford Site that have been identified to date and includes the number of units, property numbers, flow rates, uses, limitations, and characteristics. Also listed are normal storage location and usage; however, the units can be used or stored at any Hanford facility.

Appendix E contains an example of a log sheet used to track PTRAEUs and the calculations to determine maximum expected annual emissions. When implementing a PTRAEU, the responsible personne1 (operators) log the following information.

- Purpose of operation

- Location of operation

- Estimated emissions

- Date(s) and time of startup/shutdown of ventilation system

- Total hours of ventilation system operation

- Air emissions source constituents and type (1iquid, gas, solid)

- Type of control equipment connected to the unit

- Periodic confirmatory measurement.

In addition to this information, the operator determines the following.

- Emissions estimate--This information should include assumptions and the methodology used to determine the estimate. The data should be maintained by the operator and should indicate project-specific operations.

- Monitoring requirements--Includes measurement results taken during the operation. All monitoring will be in accordance with standard onsite procedures and performed by the appropriate organization(s).

A copy of the logs will be submitted annually to the DOH on February 15 . The February 15 submittal will consist of PTRAEU operations from January through December. The estimated emissions from the units will be reviewed as directed by DOE-RL and summarized in the annual radioactive air emissions report for the Hanford Site.

The recordkeeping is not in lieu of required monitoring for health, safety, DOE/RL, or contractor requirements. This recordkeeping is intended to supplement normal methods of periodic confirmatory monitoring for emissions monitoring for reporting annual actual emissions for the unit. This recordkeeping also supports the reduction of NOC applications and notification submittals required by federal and state regulations. 
The following methods will be considered appropriate for periodic confirmatory measurement, actual emission reporting:

- Nondestructive assay (NDA)

- Record sampler

- Continuous air monitoring (CAMs)

- Smear samples taken down stream of the HEPA filter.

The most appropriate method will be chosen based on requirements, such as health and safety, contractor regulatory requirements, cost, efficiency, and accessibility to the filtration and ventilation systems. Type II and III units are equipped with sampling ports in the ventilation system after filtration. Samplers will be the preferred method for ensuring compliance and reporting requirements for Type II and III units.

\subsection{RELEASE RATES (Requirement 13)}

This section provides information regarding the emission release rates from the PTRAEUs without the emission control systems in place. Also included is the effective dose equivalent (EDE) to the MEI offsite resulting from unabated emissions.

\subsection{UNABATED EMISSIONS}

Table 2 lists the unabated air emissions generated by the different types of units. The release fraction 1 E-03 for particulates was used because most activities involving PTRAEUs will involve the handling of dust, or some form of particulate radionuclide. In the case where a unit might need to handle a gas or a solid, calculations will be performed to ensure compliance with the conditions of the permit. When a solid is involved, 1 E-06 will be used; when a gas is involved, a release fraction of 1 will be used. In addition, if other controls are needed to control the release of a radionuclide in another form, a separate notification will be made to the required regulatory agency to ensure compliance with the applicable regulation. 
Table 2. Unabated Emissions.

\begin{tabular}{|c|c|c|c|}
\hline Radionuclides & $\begin{array}{c}\text { Annual possession } \\
\text { quantity } \\
\text { (curies per year) }\end{array}$ & $\begin{array}{l}\text { Appendix D } \\
\text { factor }\end{array}$ & $\begin{array}{c}\text { Annual unabated } \\
\text { emissions } \\
\text { (curies per year) }\end{array}$ \\
\hline \multicolumn{4}{|c|}{ TYPE I UNIT } \\
\hline Cs-137 & $2.08 E+02$ & 0.001 & $2.08 \mathrm{E}-01$ \\
\hline \multicolumn{4}{|c|}{ TYPE II UNIT } \\
\hline $\mathrm{Cs}-137$ & $3.6 E+00$ & 0.001 & $3.6 \mathrm{E}-03$ \\
\hline$S r-90$ & $6.6 E+00$ & 0.001 & $6.6 \mathrm{E}-03$ \\
\hline$A m-241$ & $2.2 \mathrm{E}-03$ & 0.001 & $2.2 \mathrm{E}-06$ \\
\hline \multicolumn{4}{|c|}{ TYPE III UNIT } \\
\hline $\mathrm{Cs}-137$ & $3.96 \mathrm{E}+01$ & 0.001 & $3.96 \mathrm{E}-02$ \\
\hline$S r-90$ & $7.26 \mathrm{E}+01$ & 0.001 & $7.26 \mathrm{E}-02$ \\
\hline$A m-241$ & $2.42 \mathrm{E}-02$ & 0.001 & $2.42 \mathrm{E}-05$ \\
\hline
\end{tabular}

14

15

16

\subsection{ABATED EMISSIONS}

Table 3 lists the abated air emissions generated by the different types of units. The HEPA filtration is the control equipment used on most of the units. Type II and III units are equipped with carbon adsorption; however, no credit was taken for these control units. Because most of the activities involve the handling of particulate solids, the HEPA filtration was considered the only control technology. A treatment factor of 3,000 was used when calculating the control efficiency of the HEPA systems.

If any other form of radionuclide is handled, the activity will be handled on a case-by-case basis. In addition, if other methods are needed to control the release of a radionuclide in another form, a separate notification wi 11 be made to the required regulatory agency to ensure compliance with the applicable regulation. 
28

29

30

31

40

41

42

Table 3. Abated Emissions.

\begin{tabular}{||c|c|c|c|}
\hline Radionuclides & $\begin{array}{c}\text { Annual unabated } \\
\text { emissions } \\
\text { (curies per year) }\end{array}$ & $\begin{array}{c}\text { Control } \\
\text { treatment factor } \\
\text { HEPA filtration }\end{array}$ & $\begin{array}{c}\text { Annual abated } \\
\text { emiss ions } \\
\text { (curies per year) }\end{array}$ \\
\hline \hline \multicolumn{4}{|c|}{ TYPE I UNIT } \\
\hline CS-137 & $2.08 \mathrm{E}-01$ & 0.00033 & $6.86 \mathrm{E}-05$ \\
\hline \multicolumn{4}{|c|}{ TYPE II UNIT } \\
\hline CS-137 & $3.6 \mathrm{E}-03$ & 0.00033 & $1.19 \mathrm{E}-06$ \\
\hline Sr-90 & $6.6 \mathrm{E}-03$ & 0.00033 & $2.18 \mathrm{E}-06$ \\
\hline Am-241 & $2.2 \mathrm{E}-06$ & 0.00033 & $7.26 \mathrm{E}-10$ \\
\hline \multicolumn{4}{|c|}{ TYPE III UNIT } \\
\hline Cs-137 & $1.58 \mathrm{E}-02$ & 0.00033 & $5.21 \mathrm{E}-06$ \\
\hline Sr-90 & $2.90 \mathrm{E}-02$ & 0.00033 & $9.57 \mathrm{E}-06$ \\
\hline Am-241 & $9.68 \mathrm{E}-05$ & 0.00033 & $3.19 \mathrm{E}-08$ \\
\hline
\end{tabular}

\subsection{OFFSITE IMPACT (Requirements 14 and 15)}

Hanford Site air emissions from point sources resulted in an effective dose equivalent of $2.9 \mathrm{E}-3$ millirem per year to the MEI in 1995 . The effective dose equivalent from all Hanford Site air emissions, including point sources, diffuse and fugitive sources, radon emissions, and thoron emissions, was determined to be 2.4 E-2 millirem per year to the MEI in 1995. The emissions as a result of the PTRAEUs in conjunction with other operations at the Hanford Site will not result in a violation of the National Emission Standard of 10 millirem per year.

\subsection{UNABATED DOSE}

The unabated dose to the MEI located at the Hanford Site boundary is shown in Table 4 . The 300 Area radioactive handling limits were used, along with the dose factors for the 300 Area, to demonstrate the worst-case activity that might occur during an activity using a PTRAEU. The unit dose factors included were submitted previously to the DOH (WHC 1991). The information required to develop the unit dose factors from the Clean Air Assessment

Package 1988 (CAP-88) computer code also was included in "Unit Dose Calculation Methods Summary of Facility Effluent Monitoring Plan Determinations" (WHC 1991). 
18

19

Table 4. Unabated Dose.

\begin{tabular}{|c|c|c|c|}
\hline Radionuclides & $\begin{array}{l}\text { Annual unabated } \\
\text { emiss ions } \\
\text { (curies per year) } \\
\end{array}$ & $\begin{array}{c}\text { CAP-88 unit } \\
\text { dose factor } \\
\text { (millirem/curie) } \\
\end{array}$ & $\begin{array}{l}\text { Annual unabated } \\
\text { dose } \\
\text { (mil1 irem/year) }\end{array}$ \\
\hline \multicolumn{4}{|c|}{ TYPE I UNIT } \\
\hline $\mathrm{Cs}-137$ & $2.08 \mathrm{E}-01$ & $4.77 \mathrm{E}-01$ & $9.92 \mathrm{E}-02$ \\
\hline & & TOTAL DOSE: & $9.92 \mathrm{E}-02$ \\
\hline \multicolumn{4}{|c|}{ TYPE II UNIT } \\
\hline Cs-137 & $3.6 \mathrm{E}-03$ & $4.77 \mathrm{E}-01$ & $1.72 \mathrm{E}-03$ \\
\hline $\mathrm{Sr}-90$ & $6.6 \mathrm{E}-03$ & $8.72 \mathrm{E}-01$ & $5.76 \mathrm{E}-03$ \\
\hline Am-241 & $2.2 \mathrm{E}-06$ & $2.62 E+02$ & $5.76 \mathrm{E}-04$ \\
\hline & & TOTAL DOSE: & $8.06 \mathrm{E}-03$ \\
\hline \multicolumn{4}{|c|}{ TYPE III UNIT } \\
\hline $\mathrm{Cs}-137$ & $3.96 \mathrm{E}-02$ & $4.77 \mathrm{E}-01$ & $1.89 \mathrm{E}-02$ \\
\hline $5 r-90$ & $7.26 \mathrm{E}-02$ & $8.72 \mathrm{E}-01$ & $6.33 \mathrm{E}-02$ \\
\hline Am-241 & $2.42 \mathrm{E}-05$ & $2.62 E+02$ & $6.34 \mathrm{E}-03$ \\
\hline & & TOTAL DOSE: & $8.85 \mathrm{E}-02$ \\
\hline
\end{tabular}

\subsection{ABATED DOSE}

The abated dose to the MEI located at the Hanford Site boundary is shown in Table 5. The 300 Area factors were used to indicate the worst-case activity that might be encountered. The unit dose factors included in the table are described in Section 11.1. 
4

5

6

7

8

9

10

11

12

13

14

15

16

17

18

19

20

21

22

23

24

25

26

27

28

29

30

31

32

33

34

35

36

37

Table 5. Abated Dose.

\begin{tabular}{|c|c|c|c|}
\hline Radionuclides & $\begin{array}{c}\text { Annual abated } \\
\text { emiss ions } \\
\text { (curies per year) } \\
\end{array}$ & $\begin{array}{c}\text { CAP-88 unit } \\
\text { dose factor } \\
\text { (millirem/curie) }\end{array}$ & $\begin{array}{c}\text { Annual abated } \\
\text { dose } \\
\text { (millirem/year) }\end{array}$ \\
\hline \multicolumn{4}{|c|}{ TYPE I UNIT } \\
\hline \multirow[t]{2}{*}{ Cs-137 } & $6.86 \mathrm{E}-05$ & $4.77 \mathrm{E}-01$ & $3.27 \mathrm{E}-05$ \\
\hline & & TOTAL DOSE: & $3.27 \mathrm{E}-05$ \\
\hline \multicolumn{4}{|c|}{ TYPE II UNIT } \\
\hline Cs-137 & $1.19 \mathrm{E}-06$ & $4.77 \mathrm{E}-01$ & $5.86 \mathrm{E}-05$ \\
\hline $5 r-90$ & $2.18 \mathrm{E}-06$ & $8.72 \mathrm{E}-01$ & $1.90 \mathrm{E}-06$ \\
\hline \multirow[t]{2}{*}{ Am-241 } & $7.26 \mathrm{E}-10$ & $2.62 E+02$ & $1.90 \mathrm{E}-07$ \\
\hline & & TOTAL DOSE: & $5.98 \mathrm{E}-05$ \\
\hline \multicolumn{4}{|c|}{ TYPE III UNIT } \\
\hline $\mathrm{Cs}-137$ & $5.21 \mathrm{E}-06$ & $4.77 \mathrm{E}-01$ & $2.48 \mathrm{E}-06$ \\
\hline $5 r-90$ & $9.57 \mathrm{E}-06$ & $8.72 \mathrm{E}-01$ & $8.34 \mathrm{E}-06$ \\
\hline Am-241 & $3.19 E-08$ & $2.62 E+02$ & $8.35 E-06$ \\
\hline & & TOTAL DOSE: & $1.91 \mathrm{E}-05$ \\
\hline
\end{tabular}

\subsection{FACILITY LIFETIME (Requirement 17)}

Environinental cleanup efforts on the Hanford Site are ongoing. The lifetime of the PTRAEUs depends on usage. Estimated lifetime of the PTRAEUs ranges from 5 to 10 years, depending on type.

\subsection{TECHNOLOGY STANDARDS (Requirement 18)}

The potential TEDE received by the offsite hypothetical highest receptor, resulting from the proposed operations at each of the subject fugitive emission units, is less than 0.1 millirem per year. Therefore, control technology standards 1 isted under WAC 246-247-110(18) must be met, as applicable and to the extent justified by a cost/benefit evaluation. Table 6 summarizes the extent to which the control technology standards are met. 
Table 6. Control Technology Standards.

\begin{tabular}{||l|c|l||}
\hline \multicolumn{1}{|c|}{ Standard } & $\begin{array}{c}\text { Does design } \\
\text { comply }\end{array}$ & \multicolumn{1}{|c|}{ Comment } \\
\hline \hline ASME/ANSI AG-1 & Yes & \\
\hline ASME/ANSI N509 & Yo & \\
\hline ASME/ANSI N510 & Yes & \\
\hline Nuclear Air Cleaning Handbook & Yes & \\
\hline ACGIH 1988 & No & $\begin{array}{l}\text { lo CFR 830.120 (quality } \\
\text { assurance rule) }\end{array}$ \\
\hline ANSI/ASME NQA-1 & No & $\begin{array}{l}\text { Required for NESHAPs } \\
\text { monitoring, therefore are not } \\
\text { applicable }\end{array}$ \\
\hline ANSI N13.1 & No & $\begin{array}{l}\text { Required for NESHAPs } \\
\text { monitoring, therefore are not } \\
\text { applicable }\end{array}$ \\
\hline $\begin{array}{l}\text { 40 CFR 60, Appendix A } \\
\text { Test methods: 1, 1A }\end{array}$ & $\begin{array}{l}\text { Required for NESHAPs } \\
\text { monitoring, therefore are not } \\
\text { applicable }\end{array}$ \\
\hline $\begin{array}{l}\text { 40 CFR 60, Appendix A } \\
\text { Test methods: 2, 2A, 2C, 2D }\end{array}$ & $\begin{array}{l}\text { Required for NESHAPs } \\
\text { monitoring, therefore are not } \\
\text { applicable }\end{array}$ \\
\hline $\begin{array}{l}\text { 40 CFR 60, Appendix A } \\
\text { Test methods: 4 }\end{array}$ & $\begin{array}{l}\text { Required for NESHAPs } \\
\text { monitoring, therefore are not } \\
\text { applicable }\end{array}$ \\
\hline $\begin{array}{l}\text { 40 CFR 60, Appendix A } \\
\text { Test methods: 5, 17 }\end{array}$ & No
\end{tabular}

\subsection{DISCUSSION OF BEST AVAILABLE RADIONUCLIDE CONTROL TECHNOLOGY}

It is proposed that the HEPA filtration systems, as described in Section 8.0 of the NOC, be approved as the best available radionuclide control technology (BARCT) for the PTRAEUs. The DOH has stated that HEPA filters generally are accepted as BARCT for particulate radionuclide air emissions. HEPA filter units have been used extensively on the Hanford Site to controi particulate radionuclide air emissions.

\subsection{REFERENCES}

DOE/RL-96-37, Radionuclide Air Emissions Report for the Hanford Site, Calendar Year 1995, U.S. Department of Energy, Richland Operations Office, Richland, Washington.

WHC 1991, Unit Dose Calculation Methods Summary of Facility Effluent Monitoring Plan Determinations, WHC-EP-0498, Westinghouse Hanford Company, Richland, Washington. 
DOE/RL-96-75, Rev. 0

08/96

1

2

3

4

APPENDIX A

SCHEMATICS AND DRAWINGS "TYPICAL SAMPLE PREPARATION" UNIT 
DOE/RL-96-75, Rev. 0

$08 / 96$

This page intentionally left blank. 


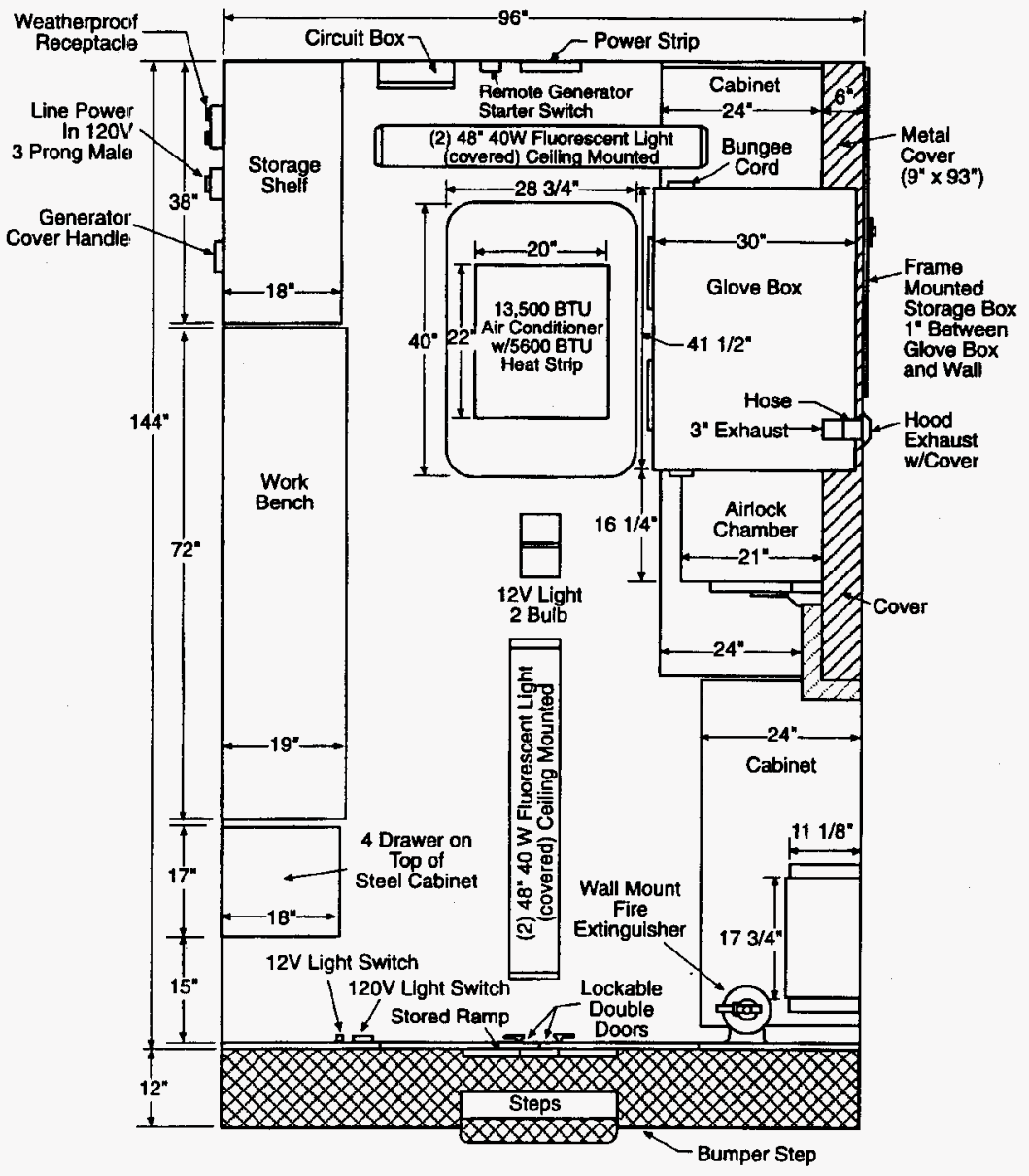

SGs5080191.5

Figure 1. Plan View. 


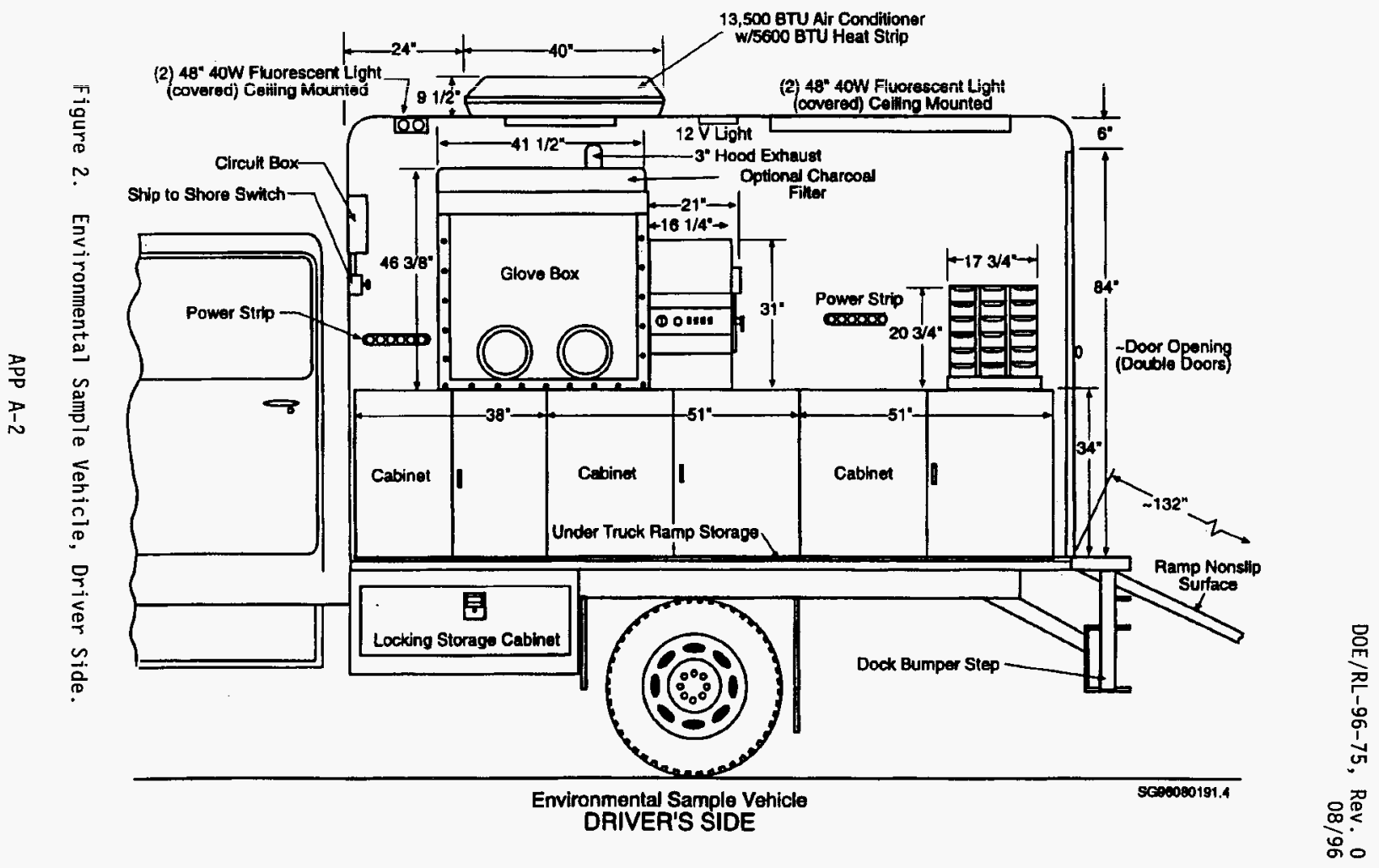




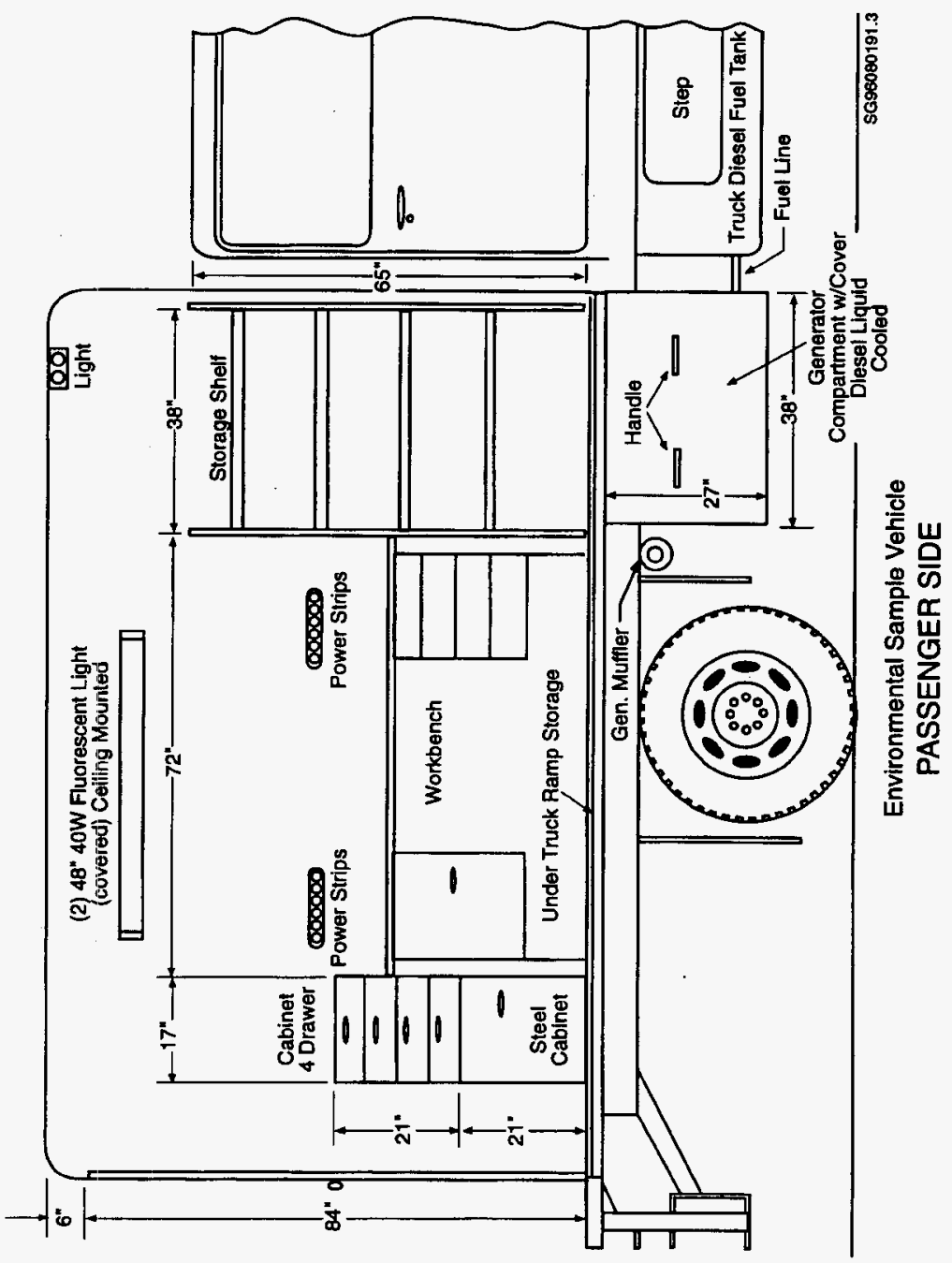

Figure 3. Environmental Sample Vehicle, Passenger Side. 

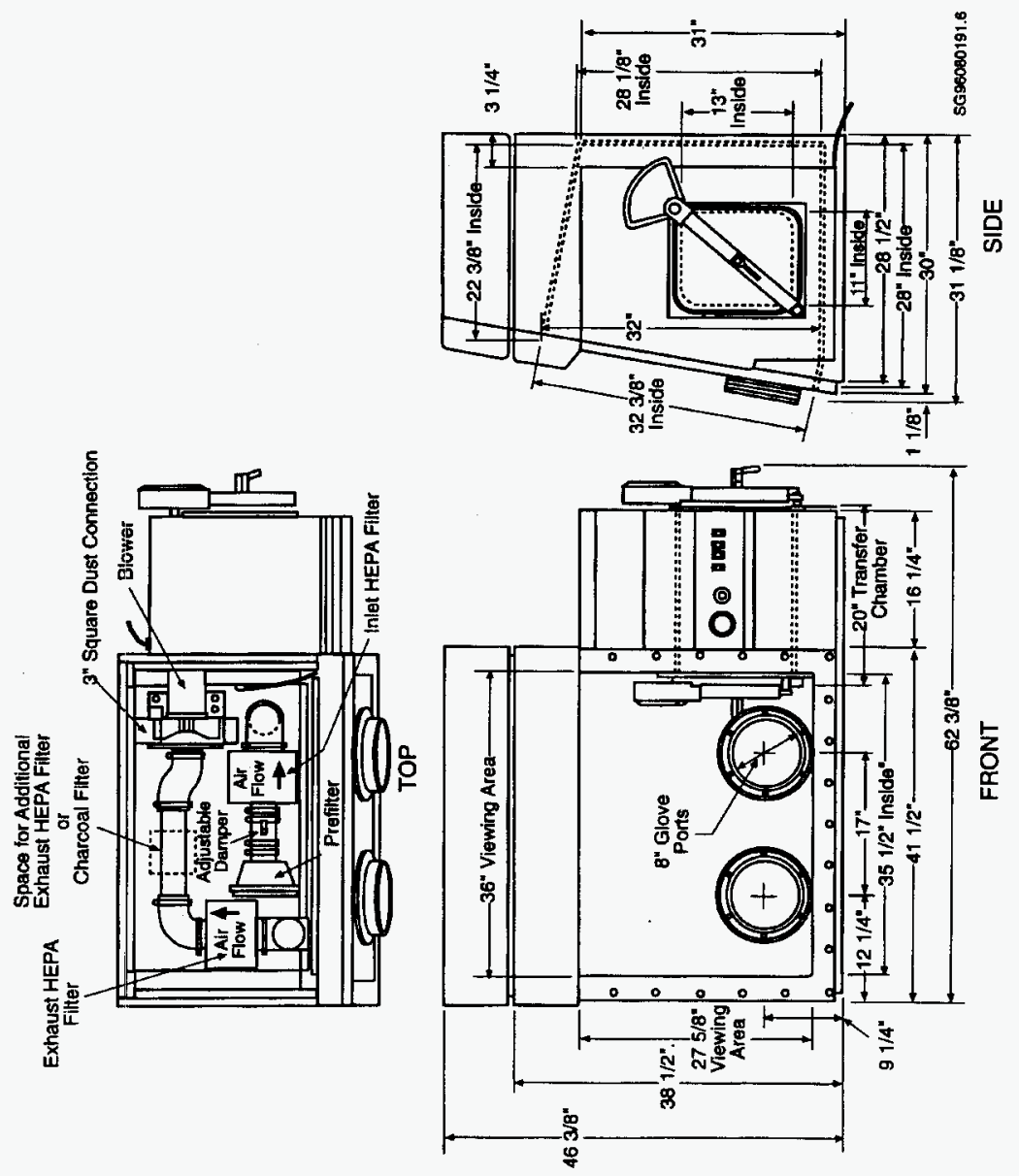

Figure 4. Hood. 

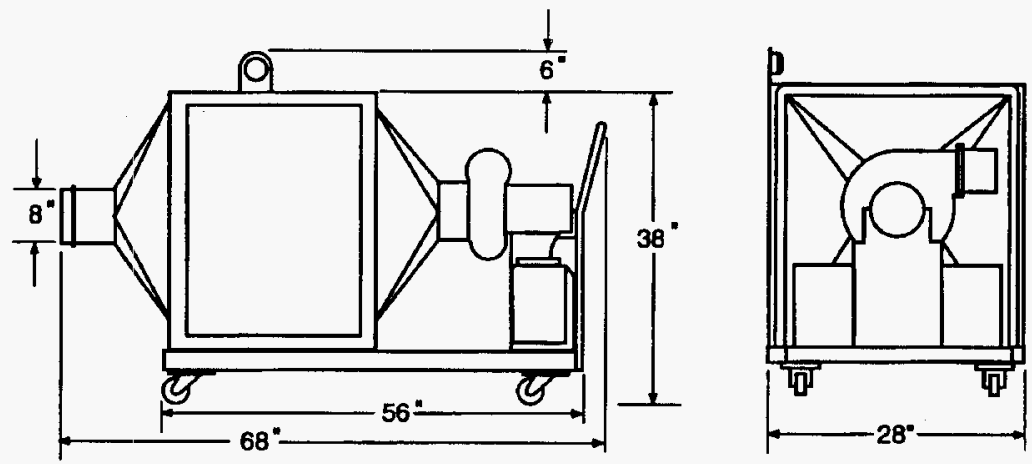

SG96080191.t

Figure 5. Portable Filtration Unit. 

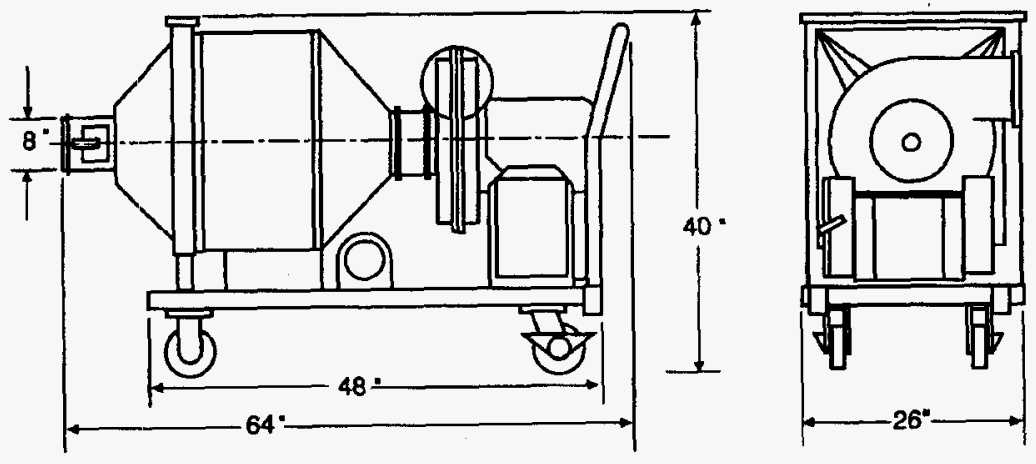

SG96080191.2

Figure 6. Portable Filter/Blower Unit. 
D0E/RL-96-75, Rev. 0 $08 / 96$

APPENDIX B

RADIOACTIVE HANDLING LIMITS 


\section{DOE/RL-96-75, Rev. 0}

$08 / 96$

This page intentionally left blank. 


\section{TABLES OF DAILY RADIOACTIVITY HANDLING LIMITS}

\section{Curies per Day}

\section{Based on the following release assumptions:}

Handling processes release 1 E-03 (emission fraction) to the effluent treatment system.

Exceptions are the inert gases ( $\mathrm{Ar}, \mathrm{Kr}, \mathrm{Xe}, \mathrm{Rn})$, tritium, ruthenium, and iodine compounds, which are assumed to be 100 percent released, and are not filtered by the effluent treatment system.

\section{Additional Considerations are the following:}

Portable ventilation-filter systems in use for more than 1 day must increase the handling limits shown on these tables according to the number of days of operations.

Sealed sources (no potential for release) need not be considered in the evaluation.

Heating above the boiling point of water will increase the release fractions. If materials will be heated to $100^{\circ} \mathrm{C}$ or more, the handling amounts must be reduced by a factor of 1,000. Exceptions are the inert gases, and tritium, ruthenium, and iodine compounds, which already include the factor of 1,000.

\section{Accomplish the following:}

1. Determine the source term to be handled during the activity

2. Determine the length of operations for the activity in days

3. Divide step 1 by step 2 to obtain curies per day

4. Divide step 3 by the RHL for each radionuclide and add up the sum of the ratios. If less than 1 , proceed under the NOC. Include all radionuclides in the potential-to-emit that could contribute $10 \%$ of the TEDE to the MEI

5. Comply with all assumptions of this NOC and this appendix. 
42

43

44

45

Table B-1. Handling Limits (curies per day) for 100-B, -C, $-K$, $-N$, and $-D$ Areas.

\begin{tabular}{|c|c|c|c|}
\hline Nuclide & Ground level & Nuclide & Ground level \\
\hline $\begin{array}{l}* \mathrm{H}-3 \\
\mathrm{C}-14 \\
\mathrm{Na}-22 \\
\mathrm{Na}-24 \\
* \mathrm{Ar}-41 \\
\mathrm{Cr}-51 \\
\mathrm{Mn}-54 \\
\mathrm{Mn}-56 \\
\mathrm{Fe}-59 \\
\mathrm{Co}-58 \\
\mathrm{Co}-60 \\
\mathrm{Ni}-63 \\
\mathrm{Zn}-65 \\
\mathrm{As}-76 \\
* \mathrm{Kr}-85 \mathrm{~m} \\
* \mathrm{Kr}-85 \\
* \mathrm{Kr}-87 \\
* \mathrm{Kr}-88 \\
\mathrm{Sr}-85 \\
\mathrm{Sr}-89 \\
\mathrm{Sr}-90 \\
\mathrm{Sr}-91 \\
\mathrm{Zr}-95 \\
\mathrm{Nb}-94 \\
\mathrm{Nb}-95 \\
\mathrm{Mo}-99 \\
\mathrm{TC}-99 \\
* \mathrm{Ru}-103 \\
* \mathrm{Ru}-106 \\
\mathrm{Sn}-113 \\
\mathrm{Sb}-124 \\
\mathrm{Sb}-125 \\
\mathrm{Sn}-126 \\
\mathrm{Te}-132 \\
* \mathrm{I}-125 \\
* \mathrm{I}-129 \\
* 1-13 \mathrm{l}\end{array}$ & $\begin{array}{ll}8.2 & E+00 \\
6.8 & E+01 \\
9.6 & E+00 \\
1.3 & E+03 \\
1.9 & E+01 \\
2.9 & E+03 \\
3.4 & E+01 \\
7.7 & E+03 \\
5.8 & E+01 \\
5.8 & E+01 \\
6.4 & E+00 \\
9.1 & E+02 \\
2.0 & E+01 \\
1.5 & E+03 \\
1.0 & E+02 \\
3.7 & E+03 \\
3.8 & E+01 \\
8.8 & E+00 \\
2.1 & E+01 \\
8.8 & E+01 \\
4.2 & E+00 \\
5.1 & E+03 \\
7.0 & E+01 \\
7.2 & E+00 \\
1.1 & E+02 \\
1.1 & E+03 \\
1.7 & E+02 \\
1.3 & E-01 \\
8.9 & E-03 \\
1.6 & E+02 \\
3.1 & E+01 \\
4.5 & E+01 \\
2.2 & E+01 \\
4.4 & E+02 \\
6.1 & E-02 \\
8.6 & E-04 \\
1.5 & E-02\end{array}$ & $\begin{array}{l}* I-132 \\
* I-133 \\
* I-135 \\
* X e-133 \\
* X e-135 \\
\text { Cs-134 } \\
\text { Cs-135 } \\
\text { Cs-137 } \\
\text { Cs-138 } \\
\text { Ba-140 } \\
\text { La-140 } \\
\text { Ce-141 } \\
\mathrm{Ce}-144 \\
\mathrm{Pm}-147 \\
\mathrm{Sm}-153 \\
\mathrm{Eu}-152 \\
\mathrm{Eu}-154 \\
\mathrm{Eu}-155 \\
\mathrm{Ra}-226 \\
\mathrm{Th}-230 \\
\mathrm{Th}-232 \\
\mathrm{U}-233 \\
\mathrm{U}-234 \\
\mathrm{U}-235 \\
\mathrm{U}-236 \\
\mathrm{U}-238 \\
\mathrm{~Np}-237 \\
\mathrm{~Np}-239 \\
\mathrm{Pu}-238 \\
\mathrm{Pu}-239 \\
\mathrm{Pu}-240 \\
\mathrm{Pu}-241 \\
\mathrm{Am}-241 \\
\mathrm{Cm}-242 \\
\mathrm{Am}-243 \\
\mathrm{Cm}-244\end{array}$ & $\begin{array}{ll}1.1 & E+01 \\
1.6 & E+00 \\
4.6 & E+00 \\
3.6 & E+02 \\
5.8 & E+01 \\
5.9 & E+00 \\
8.6 & E+01 \\
7.8 & E+00 \\
3.8 & E+04 \\
1.5 & E+02 \\
6.1 & E+02 \\
2.3 & E+02 \\
1.4 & E+01 \\
1.6 & E+02 \\
2.4 & E+03 \\
1.2 & E+01 \\
1.0 & E+01 \\
1.0 & E+02 \\
3.4 & E-01 \\
3.3 & E-02 \\
2.3 & E-02 \\
5.7 & E-02 \\
5.8 & E-02 \\
6.3 & E-02 \\
6.2 & E-02 \\
6.5 & E-02 \\
1.6 & E-02 \\
1.6 & E+03 \\
2.3 & E-02 \\
2.1 & E-02 \\
2.1 & E-02 \\
1.3 & E+00 \\
1.4 & E-02 \\
1.4 & E-02 \\
4.4 & E-01 \\
2.7 & E-02\end{array}$ \\
\hline
\end{tabular}

* Inert gases--the use of other control equipment may be required; contact appropriate organization to determine permitting needs. 
Table B-2. Handling Limits (curies per day) for 100-F and $-\mathrm{H}$ Areas.

\begin{tabular}{|c|c|c|c|}
\hline Nuclide & Ground level & Nuclide & Ground level \\
\hline 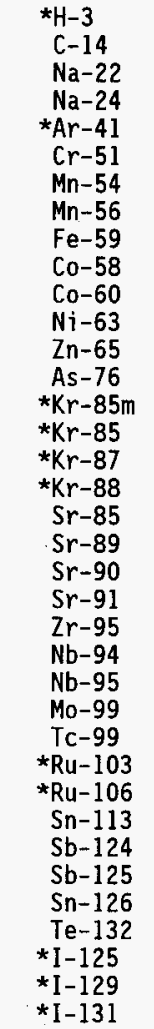 & $\begin{array}{ll}5.3 & E+00 \\
4.4 & E+01 \\
6.2 & E+00 \\
8.1 & E+02 \\
1.3 & E+01 \\
1.9 & E+03 \\
2.2 & E+01 \\
5.0 & E+03 \\
3.8 & E+01 \\
3.7 & E+01 \\
4.2 & E+00 \\
5.9 & E+02 \\
1.3 & E+01 \\
9.8 & E+02 \\
6.8 & E+01 \\
2.4 & E+03 \\
2.5 & E+01 \\
5.7 & E+00 \\
1.4 & E+01 \\
5.7 & E+01 \\
2.8 & E+00 \\
3.3 & E+03 \\
4.6 & E+01 \\
4.7 & E+00 \\
6.8 & E+01 \\
7.4 & E+02 \\
1.1 & E+02 \\
8.5 & E-02 \\
5.8 & E-03 \\
1.0 & E+02 \\
2.0 & E+01 \\
2.9 & E+01 \\
1.4 & E+01 \\
2.8 & E+02 \\
4.0 & E-02 \\
5.6 & E-04 \\
9.7 & E-03\end{array}$ & $\begin{array}{l}* I-132 \\
* I-133 \\
\star I-135 \\
* X e-133 \\
\star X e-135 \\
\mathrm{Cs}-134 \\
\mathrm{Cs}-135 \\
\mathrm{Cs}-137 \\
\mathrm{Cs}-138 \\
\mathrm{Ba}-140 \\
\mathrm{La}-140 \\
\mathrm{Ce}-141 \\
\mathrm{Ce}-144 \\
\mathrm{Pm}-147 \\
\mathrm{Sm}-153 \\
\mathrm{Eu}-152 \\
\mathrm{Eu}-154 \\
\mathrm{Eu}-155 \\
\mathrm{Ra}-226 \\
\mathrm{Th}-230 \\
\mathrm{Th}-232 \\
\mathrm{U}-233 \\
\mathrm{U}-234 \\
\mathrm{U}-235 \\
\mathrm{U}-236 \\
\mathrm{U}-238 \\
\mathrm{~Np}-237 \\
\mathrm{~Np}-239 \\
\mathrm{Pu}-238 \\
\mathrm{Pu}-239 \\
\mathrm{Pu}-240 \\
\mathrm{Pu}-241 \\
\mathrm{Am}-241 \\
\mathrm{Cm}-242 \\
\mathrm{Am}-243 \\
\mathrm{Cm}-244\end{array}$ & $\begin{array}{ll}7.2 & \mathrm{E}+00 \\
1.0 & \mathrm{E}+00 \\
3.0 & \mathrm{E}+00 \\
2.3 & \mathrm{E}+02 \\
3.8 & \mathrm{E}+01 \\
3.9 & \mathrm{E}+00 \\
5.6 & \mathrm{E}+01 \\
5.0 & \mathrm{E}+00 \\
2.5 & \mathrm{E}+04 \\
9.6 & \mathrm{E}+01 \\
4.0 & \mathrm{E}+02 \\
1.5 & \mathrm{E}+02 \\
8.8 & \mathrm{E}+00 \\
1.1 & \mathrm{E}+02 \\
1.6 & \mathrm{E}+03 \\
7.8 & \mathrm{E}+00 \\
6.6 & \mathrm{E}+00 \\
6.5 & \mathrm{E}+01 \\
2.2 & \mathrm{E}-01 \\
2.1 & \mathrm{E}-02 \\
1.5 & \mathrm{E}-02 \\
3.7 & \mathrm{E}-02 \\
3.8 & \mathrm{E}-02 \\
4.1 & \mathrm{E}-02 \\
4.0 & \mathrm{E}-02 \\
4.2 & \mathrm{E}-02 \\
1.0 & \mathrm{E}-02 \\
1.0 & \mathrm{E}+03 \\
1.5 & \mathrm{E}-02 \\
1.4 & \mathrm{E}-02 \\
1.4 & \mathrm{E}-02 \\
8.8 & \mathrm{E}-01 \\
9.2 & \mathrm{E}-03 \\
9.2 & \mathrm{E}-03 \\
2.8 & \mathrm{E}-01 \\
1.7 & \mathrm{E}-02\end{array}$ \\
\hline
\end{tabular}

* Inert gases--the use of other control equipment may be required; contact appropriate organization to determine permitting needs. 
Table B-3. Handling Limits (curies per day) for 200 West Area.

\begin{tabular}{|cc||cc||}
\hline Nuclide & Grolind leve1 & Nuclide & Ground leve 1 \\
\hline$* \mathrm{H}-3$ & $2.0 \mathrm{E}+01$ & $\mathrm{Ba}-140$ & $3.7 \mathrm{E}+02$ \\
$\mathrm{C}-14$ & $1.7 \mathrm{E}+02$ & $\mathrm{La}-140$ & $1.5 \mathrm{E}+03$ \\
$\mathrm{Na}-22$ & $2.4 \mathrm{E}+01$ & $\mathrm{Ce}-141$ & $5.6 \mathrm{E}+02$ \\
$\mathrm{Cr}-51$ & $7.3 \mathrm{E}+03$ & $\mathrm{Ce}-144$ & $3.4 \mathrm{E}+01$ \\
$\mathrm{Mn}-54$ & $8.4 \mathrm{E}+01$ & $\mathrm{Pm}-147$ & $4.1 \mathrm{E}+02$ \\
$\mathrm{Fe}-59$ & $1.4 \mathrm{E}+02$ & $\mathrm{Eu}-152$ & $3.0 \mathrm{E}+01$ \\
$\mathrm{Co}-58$ & $1.4 \mathrm{E}+02$ & $\mathrm{Eu}-154$ & $2.5 \mathrm{E}+01$ \\
$\mathrm{Co}-60$ & $1.6 \mathrm{E}+01$ & $\mathrm{Eu}-155$ & $2.5 \mathrm{E}+02$ \\
$\mathrm{Ni}-63$ & $2.3 \mathrm{E}+03$ & $* \mathrm{Rn}-220$ & $1.0 \mathrm{E}+02$ \\
$\mathrm{Zn}-65$ & $4.9 \mathrm{E}+01$ & $\mathrm{~Pb}-212$ & $1.5 \mathrm{E}+02$ \\
$* \mathrm{Kr}-85$ & $8.9 \mathrm{E}+03$ & $\mathrm{Bi}-212$ & $2.8 \mathrm{E}+03$ \\
$\mathrm{Sr}-85$ & $5.3 \mathrm{E}+01$ & $\mathrm{Ra}-226$ & $8.5 \mathrm{E}-01$ \\
$\mathrm{Sr}-89$ & $2.2 \mathrm{E}+02$ & $\mathrm{Th}-230$ & $8.1 \mathrm{E}-02$ \\
$\mathrm{Sr}-90$ & $1.1 \mathrm{E}+01$ & $\mathrm{Th}-232$ & $5.7 \mathrm{E}-02$ \\
$\mathrm{Zr}-95$ & $1.7 \mathrm{E}+02$ & $\mathrm{U}-233$ & $1.4 \mathrm{E}-01$ \\
$\mathrm{Nb}-94$ & $1.8 \mathrm{E}+01$ & $\mathrm{U}-234$ & $1.4 \mathrm{E}-01$ \\
$\mathrm{Nb}-95$ & $2.6 \mathrm{E}+02$ & $\mathrm{U}-235$ & $1.6 \mathrm{E}-01$ \\
$\mathrm{Tc}-99$ & $4.2 \mathrm{E}+02$ & $\mathrm{U}-236$ & $1.5 \mathrm{E}-01$ \\
$* \mathrm{Ru}-103$ & $3.2 \mathrm{E}-01$ & $\mathrm{U}-238$ & $1.6 \mathrm{E}-01$ \\
$* \mathrm{Ru}-106$ & $2.2 \mathrm{E}-02$ & $\mathrm{~Np}-237$ & $3.9 \mathrm{E}-02$ \\
$\mathrm{Sn}-113$ & $3.9 \mathrm{E}+02$ & $\mathrm{~Np}-239$ & $4.0 \mathrm{E}+03$ \\
$\mathrm{Sb}-124$ & $7.6 \mathrm{E}+01$ & $\mathrm{Pu}-238$ & $5.8 \mathrm{E}-02$ \\
$\mathrm{Sb}-125$ & $1.1 \mathrm{E}+02$ & $\mathrm{Pu}-239$ & $5.3 \mathrm{E}-02$ \\
$\mathrm{Sn}-126$ & $5.4 \mathrm{E}+01$ & $\mathrm{Pu}-240$ & $5.3 \mathrm{E}-02$ \\
$* \mathrm{I}-125$ & $1.7 \mathrm{E}-01$ & $\mathrm{Pu}-241$ & $3.4 \mathrm{E}+00$ \\
$* \mathrm{I}-129$ & $2.4 \mathrm{E}-03$ & $\mathrm{Am}-241$ & $3.5 \mathrm{E}-02$ \\
$* \mathrm{I}-131$ & $4.2 \mathrm{E}-02$ & $\mathrm{Am}-243$ & $3.5 \mathrm{E}-02$ \\
$\mathrm{Cs}-134$ & $1.5 \mathrm{E}+01$ & $\mathrm{Cm}-242$ & $1.1 \mathrm{E}+00$ \\
$\mathrm{Cs}-135$ & $2.1 \mathrm{E}+02$ & $\mathrm{Cm}-244$ & $6.6 \mathrm{E}-02$ \\
$\mathrm{Cs}-137$ & $1.9 \mathrm{E}+01$ & & \\
\hline & & & \\
\hline
\end{tabular}

* Inert gases--the use of other control equipment may be required; contact appropriate organization to determine permitting needs. 
Table B-4. Handling Limits (curies per day) for 200 East Area.

\begin{tabular}{|c|c|c|c|}
\hline Nuclide & Ground level & Nuclide & Ground level \\
\hline $\begin{array}{l}* \mathrm{H}-3 \\
\mathrm{C}-14 \\
\mathrm{Na}-22 \\
\mathrm{Cr}-5 \mathrm{l} \\
\mathrm{Mn}-54 \\
\mathrm{Fe}-59 \\
\mathrm{Co}-58 \\
\mathrm{Co}-60 \\
\mathrm{Ni}-63 \\
\mathrm{Zn}-65 \\
\star \mathrm{Kr}-85 \\
\mathrm{Sr}-85 \\
\mathrm{Sr}-89 \\
\mathrm{Sr}-90 \\
\mathrm{Zr}-95 \\
\mathrm{Nb}-94 \\
\mathrm{Nb}-95 \\
\mathrm{Tc}-99 \\
\star \mathrm{Ru}-103 \\
\star \mathrm{Ru}-106 \\
\mathrm{Sn}-113 \\
\mathrm{Sb}-124 \\
\mathrm{Sb}-125 \\
\mathrm{Sn}-126 \\
\star \mathrm{I}-125 \\
\star \mathrm{I}-129 \\
\star \mathrm{I}-131 \\
\mathrm{Cs}-134 \\
\mathrm{Cs}-135 \\
\mathrm{Cs}-137\end{array}$ & $\begin{array}{ll}1.3 & E+01 \\
1.0 & E+02 \\
1.4 & E+01 \\
4.3 & E+03 \\
5.0 & E+01 \\
8.6 & E+01 \\
8.5 & E+01 \\
9.4 & E+00 \\
1.3 & E+03 \\
2.9 & E+01 \\
5.6 & E+03 \\
3.1 & E+01 \\
1.3 & E+02 \\
6.3 & E+00 \\
1.0 & E+02 \\
1.1 & E+01 \\
1.6 & E+02 \\
2.5 & E+02 \\
1.9 & E-01 \\
1.3 & E-02 \\
2.3 & E+02 \\
4.6 & E+01 \\
6.6 & E+01 \\
3.2 & E+01 \\
6.7 & E-02 \\
9.4 & E-04 \\
1.6 & E-02 \\
8.8 & E+00 \\
1.3 & E+02 \\
1.1 & E+01\end{array}$ & $\begin{array}{l}\mathrm{Ba}-140 \\
\mathrm{La}-140 \\
\mathrm{Ce}-141 \\
\mathrm{Ce}-144 \\
\mathrm{Pm}-147 \\
\mathrm{Eu}-152 \\
\mathrm{Eu}-154 \\
\mathrm{Eu}-155 \\
\text { *Rn-220 } \\
\mathrm{Pb}-212 \\
\mathrm{Bi}-212 \\
\mathrm{Ra}-226 \\
\mathrm{Th}-230 \\
\mathrm{Th}-232 \\
\mathrm{U}-233 \\
\mathrm{U}-234 \\
\mathrm{U}-235 \\
\mathrm{U}-236 \\
\mathrm{U}-238 \\
\mathrm{~Np}-237 \\
\mathrm{~Np}-239 \\
\mathrm{Pu}-238 \\
\mathrm{Pu}-239 \\
\mathrm{Pu}-240 \\
\mathrm{Pu}-241 \\
\mathrm{Am}-241 \\
\mathrm{Am}-243 \\
\mathrm{Cm}-242 \\
\mathrm{Cm}-244\end{array}$ & $\begin{array}{ll}2.2 & \mathrm{E}+02 \\
9.0 & \mathrm{E}+02 \\
3.3 & \mathrm{E}+02 \\
2.0 & \mathrm{E}+01 \\
2.4 & \mathrm{E}+02 \\
1.8 & \mathrm{E}+01 \\
1.5 & \mathrm{E}+01 \\
1.5 & \mathrm{E}+02 \\
5.7 & \mathrm{E}+01 \\
8.3 & \mathrm{E}+01 \\
1.0 & \mathrm{E}+03 \\
5.0 & \mathrm{E}-01 \\
4.8 & \mathrm{E}-02 \\
3.4 & \mathrm{E}-02 \\
8.5 & \mathrm{E}-02 \\
8.6 & \mathrm{E}-02 \\
9.3 & \mathrm{E}-02 \\
9.1 & \mathrm{E}-02 \\
9.6 & \mathrm{E}-02 \\
2.3 & \mathrm{E}-02 \\
2.4 & \mathrm{E}+03 \\
3.4 & \mathrm{E}-02 \\
3.2 & \mathrm{E}-02 \\
3.2 & \mathrm{E}-02 \\
2.0 & \mathrm{E}-02 \\
2.1 & \mathrm{E}-02 \\
2.1 & \mathrm{E}-02 \\
6.5 & \mathrm{E}-01 \\
3.9 & \mathrm{E}-02\end{array}$ \\
\hline
\end{tabular}

* Inert gases--the use of other control equipment may be required; contact appropriate organization to determine permitting needs. 
Table B-5. Handling Limits (curies per day) for the 300 Area.

\begin{tabular}{|c|c|c|c|}
\hline Nuclide & Ground level & Nuclide & Ground level \\
\hline $\begin{array}{c}* \mathrm{H}-3 \\
\mathrm{C}-14 \\
\mathrm{Na}-22 \\
\mathrm{Cr}-51 \\
\mathrm{Mn}-54 \\
\mathrm{Fe}-59 \\
\mathrm{Co}-58 \\
\mathrm{Co}-60 \\
\mathrm{Ni}-63 \\
\mathrm{Zn}-65 \\
* \mathrm{Kr}-85 \\
\mathrm{Sr}-85 \\
\mathrm{Sr}-89 \\
\mathrm{Sr}-90 \\
\mathrm{Zr}-95 \\
\mathrm{Nb}-94 \\
\mathrm{Nb}-95 \\
\mathrm{Tc}-99 \mathrm{~m} \\
\mathrm{Tc}-99 \\
* \mathrm{Ru}-103 \\
* \mathrm{Ru}-106 \\
\mathrm{Sn}-113 \\
\mathrm{Sb}-124 \\
\mathrm{Sb}-125 \\
\mathrm{Sn}-126 \\
* \mathrm{I}-125 \\
* \mathrm{I}-129 \\
* \mathrm{I}-131 \\
\mathrm{Cs}-134\end{array}$ & $\begin{array}{ll}6.9 & E-01 \\
5.8 & E+00 \\
7.1 & E-01 \\
2.2 & E+02 \\
2.5 & E+00 \\
4.3 & E+00 \\
4.3 & E+00 \\
4.7 & E-01 \\
6.8 & E+01 \\
1.5 & E+00 \\
2.7 & E+02 \\
1.6 & E+00 \\
6.5 & E+00 \\
3.1 & E-01 \\
5.2 & E+00 \\
5.3 & E-01 \\
7.8 & E+00 \\
3.8 & E+03 \\
1.3 & E+01 \\
9.7 & E-03 \\
6.6 & E-04 \\
1.2 & E+01 \\
2.3 & E+00 \\
3.3 & E+00 \\
1.6 & E+00 \\
1.5 & E-03 \\
2.1 & E-05 \\
3.7 & E-04 \\
4.4 & E-01\end{array}$ & $\begin{array}{l}\mathrm{Cs}-135 \\
\mathrm{Cs}-137 \\
\mathrm{Ba}-140 \\
\mathrm{La}-140 \\
\mathrm{Ce}-141 \\
\mathrm{Ce}-144 \\
\mathrm{Pm}-147 \\
\mathrm{Eu}-152 \\
\mathrm{Eu}-154 \\
\mathrm{Eu}-155 \\
\mathrm{Ra}-226 \\
\mathrm{Th}-230 \\
\mathrm{Th}-232 \\
U-233 \\
\mathrm{U}-234 \\
\mathrm{U}-235 \\
\mathrm{U}-236 \\
\mathrm{U}-238 \\
\mathrm{~Np}-237 \\
\mathrm{~Np}-239 \\
\mathrm{Pu}-238 \\
\mathrm{Pu}-239 \\
\mathrm{Pu}-240 \\
\mathrm{Pu}-241 \\
\mathrm{Am}-241 \\
\mathrm{Am}-243 \\
\mathrm{Cm}-242 \\
\mathrm{Cm}-244\end{array}$ & $\begin{array}{ll}6.4 & \mathrm{E}+00 \\
5.7 & \mathrm{E}-01 \\
1.1 & \mathrm{E}+01 \\
4.5 & \mathrm{E}+01 \\
1.7 & \mathrm{E}+01 \\
1.0 & \mathrm{E}+00 \\
1.2 & \mathrm{E}+01 \\
8.9 & \mathrm{E}-01 \\
7.5 & \mathrm{E}-01 \\
7.4 & \mathrm{E}+00 \\
2.5 & \mathrm{E}-02 \\
2.4 & \mathrm{E}-03 \\
1.7 & \mathrm{E}-03 \\
4.3 & \mathrm{E}-03 \\
4.3 & \mathrm{E}-03 \\
4.6 & \mathrm{E}-03 \\
4.6 & \mathrm{E}-03 \\
4.8 & \mathrm{E}-03 \\
1.2 & \mathrm{E}-03 \\
1.2 & \mathrm{E}+02 \\
1.7 & \mathrm{E}-03 \\
1.6 & \mathrm{E}-03 \\
1.6 & \mathrm{E}-03 \\
1.0 & \mathrm{E}-01 \\
1.0 & \mathrm{E}-03 \\
1.0 & \mathrm{E}-03 \\
3.2 & \mathrm{E}-02 \\
2.0 & \mathrm{E}-03\end{array}$ \\
\hline
\end{tabular}

* Inert gases--the use of other control equipment may be required; contact appropriate organization to determine permitting needs. 
Table B-6. Hand7ing Limits (curies per day) for the 400 Area.

\begin{tabular}{|c|c|c|c|}
\hline Nuclide & Ground level & Nuclide & Ground level \\
\hline 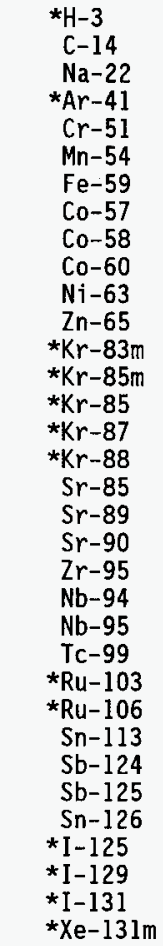 & $\begin{array}{ll}9.7 & E+00 \\
8.1 & E+01 \\
1.1 & E+01 \\
1.7 & E+01 \\
3.3 & E+03 \\
3.8 & E+01 \\
6.5 & E+01 \\
1.7 & E+02 \\
6.4 & E+01 \\
7.1 & E+00 \\
1.0 & E+03 \\
2.2 & E+01 \\
9.2 & E+00 \\
1.1 & E+02 \\
4.3 & E+03 \\
2.9 & E+01 \\
8.4 & E+00 \\
2.4 & E+01 \\
9.8 & E+01 \\
4.7 & E+00 \\
7.8 & E+01 \\
8.0 & E+00 \\
1.2 & E+02 \\
1.9 & E+02 \\
1.5 & E-01 \\
9.9 & E-03 \\
1.8 & E+02 \\
3.4 & E+01 \\
5.0 & E+01 \\
2.4 & E+01 \\
4.2 & E-02 \\
5.8 & E-04 \\
1.0 & E-02 \\
1.5 & E+03\end{array}$ & $\begin{array}{l}\text { * Xe-133m } \\
\text { * Xe-133 } \\
\star X e-135 m \\
\star X e-135 \\
\mathrm{Cs}-134 \\
\mathrm{Cs}-135 \\
\mathrm{Cs}-137 \\
\mathrm{Ba}-140 \\
\mathrm{La}-140 \\
\mathrm{Ce}-141 \\
\mathrm{Ce}-144 \\
\mathrm{Pm}-147 \\
\mathrm{Eu}-152 \\
\mathrm{Eu}-154 \\
\mathrm{Eu}-155 \\
\mathrm{Ra}-226 \\
\mathrm{Th}-230 \\
\mathrm{Th}-232 \\
\mathrm{U}-233 \\
\mathrm{U}-234 \\
\mathrm{U}-235 \\
\mathrm{U}-236 \\
\mathrm{U}-238 \\
\mathrm{~Np}-237 \\
\mathrm{~Np}-239 \\
\mathrm{Pu}-238 \\
\mathrm{Pu}-239 \\
\mathrm{Pu}-240 \\
\mathrm{Pu}-241 \\
\mathrm{Am}-241 \\
\mathrm{Am}-243 \\
\mathrm{Cm}-242 \\
\mathrm{Cm}-244\end{array}$ & $\begin{array}{ll}4.8 & \mathrm{E}+02 \\
4.2 & \mathrm{E}+02 \\
2.9 & \mathrm{E}+02 \\
6.4 & \mathrm{E}+01 \\
6.6 & \mathrm{E}+00 \\
9.6 & \mathrm{E}+01 \\
8.6 & \mathrm{E}+00 \\
1.6 & \mathrm{E}+02 \\
6.8 & \mathrm{E}+02 \\
2.5 & \mathrm{E}+02 \\
1.5 & \mathrm{E}+01 \\
1.8 & \mathrm{E}+02 \\
1.3 & \mathrm{E}+01 \\
1.1 & \mathrm{E}+01 \\
1.1 & \mathrm{E}+02 \\
3.8 & \mathrm{E}-01 \\
3.6 & \mathrm{E}-02 \\
2.5 & \mathrm{E}-02 \\
6.4 & \mathrm{E}-02 \\
6.5 & \mathrm{E}-02 \\
7.0 & \mathrm{E}-02 \\
6.9 & \mathrm{E}-02 \\
7.3 & \mathrm{E}-02 \\
1.7 & \mathrm{E}-02 \\
1.8 & \mathrm{E}+03 \\
2.6 & \mathrm{E}-02 \\
2.4 & \mathrm{E}-02 \\
2.4 & \mathrm{E}-02 \\
1.5 & \mathrm{E}+00 \\
1.6 & \mathrm{E}-02 \\
1.6 & \mathrm{E}-02 \\
4.9 & \mathrm{E}-01 \\
3.0 & \mathrm{E}-02\end{array}$ \\
\hline
\end{tabular}

* Inert gases--the use of other control equipment may be required; contact appropriate organization to determine permitting needs. 
D0E/RL-96-75, Rev. 0

This page intentionally left blank. 
DOE/RL-96-75, Rev. 0

$08 / 96$

\section{APPENDIX C}

SAMPLE DATA USED FOR TYPE II AND III UNITS

APP $\mathbf{C}-\mathbf{i}$ 
D0E/RL-96-75, Rev. 0

08/96

1
2
3
4
5

This page intentionally left, blank.

. 
25

26

27

28

29

30

31

32

33

\section{Example Calculation of Expected Maximum Activities}

The expected maximum activity calculations in this appendix are for a single PTRAEU, specifically a mobile sample preparation facility and sample screening and analysis facility. This example has been provided to demonstrate the method of calculating the expected maximum activities for cesium-137, strontium-90, and americium-241. Although more than one PTRAEU will be in operation at any time, it is not expected that all PTRAEUs will handle radiologically contaminated media. Each of the PTRAEUs will operate under the same conditions and limitations as specified in this application.

The maximum soil concentrations in cribs located north of the 241-BY Tank Farm were determined in the following manner. The total activity discharged to the crib was taken from the Waste Information Data System and decayed to 1989. The soil volumes were conservative assumptions to determine the potential maximum soil concentrations. The assumptions for these soil volumes are as follows. The total activity was divided by the soil volume to determine the potential maximum soil concentration.

Table C-l. Soil Concentrations of Radionuclides Within Specified Cribs.

\begin{tabular}{|c|c|c|c|c|c|c|c|}
\hline \multirow[t]{2}{*}{$\begin{array}{l}\text { Crib ID } \\
\text { number }\end{array}$} & \multirow[t]{2}{*}{$\begin{array}{c}\text { Soil } \\
\text { volume } \\
\text { (cubic } \\
\text { meters) }\end{array}$} & \multicolumn{3}{|c|}{$\begin{array}{c}\text { Total activity discharged } \\
\text { to the crib } \\
\text { (decayed to 1989) } \\
\text { (curies) }\end{array}$} & \multicolumn{3}{|c|}{$\begin{array}{l}\text { Soil concentration } \\
\text { (microcuries per cubic } \\
\text { centimeter) }\end{array}$} \\
\hline & & $5 r-90$ & & Am-241 & $S r-90$ & $\mathrm{Cs}-137$ & Am-241 \\
\hline $216-B-43$ & 142 & 574 & 130 & 0.0104 & $4.0 E+00$ & $0.92 E+00$ & $7.3 \mathrm{E}-05$ \\
\hline $216-B-44$ & 142 & 1200 & 309 & 0.311 & $8.5 E+00$ & $2.2 \quad E+00$ & $2.2 \quad E-03$ \\
\hline $216-B-45$ & 142 & 1180 & 666 & 0.207 & $8.3 E+00$ & $4.7 \quad \mathrm{E}+00$ & $1.5 \mathrm{E}-03$ \\
\hline $216-B-46$ & 142 & 631 & 88.0 & 0.414 & $4.4 E+00$ & $0.62 E+00$ & $2.9 \mathrm{E}-03$ \\
\hline $216-B-47$ & 142 & 261 & 66.0 & 0.104 & $1.8 \mathrm{E}+00$ & $0.46 \mathrm{E}+00$ & $7.3 \quad E-04$ \\
\hline $216-B-48$ & 142 & 547 & 200 & 0.104 & $3.9 E+00$ & $1.4 \quad E+00$ & 7.3 E-04 \\
\hline $216-B-49$ & 142 & 1140 & 182 & 0.311 & $8.0 E+00$ & $1.3 \mathrm{E}+00$ & 2.2 E-03 \\
\hline $216-8-50$ & 142 & 3.39 & 51.2 & 0.00495 & $0.02 E+00$ & $0.36 \mathrm{E}+00$ & $3.5 \mathrm{E}-05$ \\
\hline $216-B-57$ & 170 & 1.83 & 226 & 0.00387 & $0.01 E+00$ & $1.3 \quad E+00$ & $2.7 \mathrm{E}-05$ \\
\hline
\end{tabular}




\section{Assumptions for Contaminated Soil Volumes \\ Cribs $216-B-43$ to $216-B-50$}

Small cylinder, radius 6.1 meters, thickness 1.2 meters (a worst case to maximize soil concentrations). Soil volume is 142 cubic meters.

\section{Crib 216-B-57}

Rectangular slab 4.6 meters wide, 30.5 meters long (half the actual length of the crib, to be conservative), and 1.2 meters thick. Soil volume is 170 cubic meters. This is the smallest reasonable volume of soil where radioactivity has spread.

The total activity expected in the largest sample at the highest soil concentrations (i.e., at Crib 216-B-44 for Sr-90, Crib 216-B-45 for Cs-137, and at Crib 216-B-46 for Am-241) is shown in Table 2. These are the maximum total activities, which were used in the example calculation in Appendix $E$.

Table C-2. Radionuclide Source Term (curies) in Soil Sample.

\begin{tabular}{|c|c|c|c|c|}
\hline Sample type & $\begin{array}{l}\text { Largest sample } \\
\text { soil volume } \\
\text { (cubic } \\
\text { centimeters) }\end{array}$ & $\begin{array}{l}\text { Maximum } \\
S r-90\end{array}$ & $\begin{array}{l}\text { total act } \\
\text { (curies) } \\
\text { Cs-137 }\end{array}$ & $\begin{array}{l}\text { ity } \\
\text { Am-241 }\end{array}$ \\
\hline $\begin{array}{c}0.61 \text { meter long, } \\
\text { 12.7-centimeter } \\
\text { diameter }\end{array}$ & 7,722 & $6.6 E-02$ & $3.6 \mathrm{E}-02$ & $2.2 \mathrm{E}-05$ \\
\hline
\end{tabular}


DOE/RL-96-75, Rev. 0

08/96

APPENDIX D

PORTABLE/TENPORARY RADIONUCLIDE AIRBORNE ENISSION UNIT LISTING 
D0E/RL-96-75, Rev. 0

$08 / 96$

1

2

3

This page intentionally left blank. 
12

13

14

15

\begin{tabular}{||c|c|c|}
\hline Unit & $\begin{array}{c}\text { Number } \\
\text { of } \\
\text { units }\end{array}$ & $\begin{array}{c}\text { Identification } \\
\text { number }\end{array}$ \\
\hline
\end{tabular}

The units listed in this appendix are used and managed by onsite contractors. Headings indicate typical site use and storage locations of the units; however, the units are not limited to those areas and can be used anywhere on the Hanford Site in accordance with the terms and conditions of the NOCs.

\section{HANFORD SITE PORTABLE/TEMPORARY EMISSIONS UNITS}

\section{Environmental Restoration Contractor (N Reactor)--}

\begin{tabular}{|l|l|l|l|l|l|}
\hline Type I & 1 & IP2A078401 & 176 & $\begin{array}{l}\text { Greenhouse } \\
\text { ventilation }\end{array}$ & $\begin{array}{l}\text { HEPA filter; } \\
\begin{array}{l}99.97 \% \\
\text { efficiency }\end{array}\end{array}$ \\
\hline
\end{tabular}

Environmental Restoration Contractor (a11 others)--

\begin{tabular}{|l|l|l|l|l|l|}
\hline Type I & 1 & 0050979 & $500-2,000$ & Ventilation & $\begin{array}{l}\text { 1 prefilter; } \\
\text { 1 secondary } \\
\text { filter: } \\
\text { HEPA filter; } \\
1.5 \text { horsepower } \\
\text { electric motor } \\
\text { (110 vaC); flow } \\
\text { rate indicator } \\
\text { (magnehelic); } \\
\text { audible 10w flow } \\
\text { alarm at } \\
\text { 2.5 inches water } \\
\text { pressure gauge }\end{array}$ \\
\hline Type I & 1 & B55220 & 2,000 & Ventilation & $\begin{array}{l}\text { HEPA filter; } \\
99.97 \% \\
\text { efficiency }\end{array}$ \\
\hline Type I & 1 & 2399 & 3,000 & Ventilation & $\begin{array}{l}\text { HEPA filter; } \\
99.97 \% \\
\text { efficiency }\end{array}$ \\
\hline Type I & 1 & 2579 & 3,000 & Ventilation & $\begin{array}{l}\text { HEPA filter; } \\
\text { 99.97\% } \\
\text { efficiency }\end{array}$ \\
\hline
\end{tabular}


D0E/RL-96-75, Rev. 0

08/96

\begin{tabular}{|c|c|c|c|c|c|}
\hline Unit & $\begin{array}{c}\text { Number } \\
\text { of } \\
\text { units }\end{array}$ & $\begin{array}{c}\text { Identification } \\
\text { number }\end{array}$ & $\begin{array}{l}\text { Flow rate } \\
\text { (cubic } \\
\text { feet per } \\
\text { minute) }\end{array}$ & Uses & Characteristics \\
\hline \multicolumn{6}{|c|}{ Environmental Engineering (B Plant Complex)-- } \\
\hline Type I & 1 & P0 6-4409 72-1A & 1,650 & $\begin{array}{l}\text { Asbestos } \\
\text { removal or } \\
\text { prevention of } \\
\text { contamination } \\
\text { spread at } \\
\text { B Plant } \\
\text { Complex of } \\
\text { Waste } \\
\text { Encapsulation } \\
\text { and Storage } \\
\text { Facility } \\
\text { (WESF) }\end{array}$ & $\begin{array}{l}\text { HEPA filter } \\
\text { D/P-- } 1.2 \text { inches } \\
\text { water column } \\
99.97 \% \\
\text { efficiency at } \\
0.3 \text { micron }\end{array}$ \\
\hline Type I & 1 & $9042015-020$ & 125 & $\begin{array}{l}\text { WESF ion } \\
\text { exchange clean } \\
\text { out. Al so use } \\
\text { will include } \\
\text { prevention of } \\
\text { contamination } \\
\text { spread at } \\
\text { B Plant } \\
\text { Complex or } \\
\text { WESF. }\end{array}$ & $\begin{array}{l}\text { HEPA filter } \\
99.97 \% \\
\text { efficiency at } \\
0.3 \text { microns }\end{array}$ \\
\hline \multicolumn{6}{|c|}{300 Area Support Service-- } \\
\hline Type I & 1 & 9470005 & 77 & $\begin{array}{l}\text { Asbestos } \\
\text { abatement }\end{array}$ & $\begin{array}{l}\text { HEPA filter that } \\
\text { removes } 99.999 \% \\
\text { of all particles } \\
\text { of } 0.3 \text { micron } \\
\text { size or larger } \\
\text { with a } 4 \text {-gallon } \\
\text { collection bag }\end{array}$ \\
\hline Type I & 1 & 9500011 & 77 & Vacuuming ${ }^{1}$ & $\begin{array}{l}\text { HEPA filter that } \\
\text { removes } 99.999 \% \\
\text { of all particles } \\
\text { of } 0.3 \text { micron } \\
\text { size or larger } \\
\text { with a } 4 \text {-gailon } \\
\text { collection bag }\end{array}$ \\
\hline
\end{tabular}




\begin{tabular}{|c|c|c|c|c|c|}
\hline Unit & $\begin{array}{c}\text { Number } \\
\text { of } \\
\text { units }\end{array}$ & $\begin{array}{c}\text { Identification } \\
\text { number }\end{array}$ & $\begin{array}{l}\text { Flow rate } \\
\text { (cubic } \\
\text { feet per } \\
\text { minute) } \\
\end{array}$ & Uses & Characteristics \\
\hline Type I & 1 & 3440009 & 77 & Vacuuming $^{1}$ & $\begin{array}{l}\text { HEPA filter that } \\
\text { removes } 99.999 \% \\
\text { of all particles } \\
\text { of } 0.3 \text { micron } \\
\text { size or larger } \\
\text { with a } 4 \text {-gallon } \\
\text { collection bag } \\
\end{array}$ \\
\hline Type I & 1 & 12632 & 1,000 & $\begin{array}{l}\text { Air flow } \\
\text { control and } \\
\text { negative } \\
\text { pressure or } \\
\text { confinements } \\
\text { for } \\
\text { radiological } \\
\text { control }\end{array}$ & $\begin{array}{l}\text { HEPA filter; } \\
\text { D/P }-1.05^{4} \text { water } \\
\text { column }\end{array}$ \\
\hline \multicolumn{6}{|c|}{ Regulatory Compliance (PUREX Facility) -- } \\
\hline Type I & 1 & MT 201 & 1,089 & $\begin{array}{l}\text { Asbestos } \\
\text { removal }\end{array}$ & $\begin{array}{l}\text { HEPA filter; } \\
\text { D/P-- } 1.2 \text { inches } \\
\text { water column } \\
99.99 \% \\
\text { efficiency at } \\
0.3 \text { micron } \\
\end{array}$ \\
\hline Type I & 1 & 04167 & 884 & $\begin{array}{l}\text { General } \\
\text { removal }\end{array}$ & $\begin{array}{l}\text { HEPA filter } \\
\text { D/P-- } 1.2 \text { inches } \\
\text { water col umn }\end{array}$ \\
\hline Type I & 1 & $9900-2000-0845$ & 1,155 & $\begin{array}{l}\text { Stored in } \\
\text { storage } \\
\text { gallery } \\
\text { (greenhouse) } \\
\end{array}$ & $\begin{array}{l}\text { HEPA filter } \\
\text { D/P--2.2 inches } \\
\text { water column }\end{array}$ \\
\hline Type I & 1 & WB56633 & 190 & $\begin{array}{l}\text { Wash and } \\
\text { vacuum }\end{array}$ & $\begin{array}{l}\text { HEPA filter } \\
99.97 \% \\
\text { efficiency at } \\
0.3 \text { micron } \\
\end{array}$ \\
\hline Type I & 1 & MT 12724 & 758 & $\begin{array}{l}\text { Stored in a } \\
\text { power cage } \\
\text { (greenhouse) }\end{array}$ & $\begin{array}{l}\text { HEPA filter } \\
\text { D/P-- } 1.05 \text { inches } \\
\text { water column }\end{array}$ \\
\hline
\end{tabular}




\begin{tabular}{|c|c|c|c|c|c|}
\hline Unit & $\begin{array}{c}\text { Number } \\
\text { of } \\
\text { units }\end{array}$ & $\begin{array}{c}\text { Identification } \\
\text { number }\end{array}$ & $\begin{array}{l}\text { Flow rate } \\
\text { (cubic } \\
\text { feet per } \\
\text { minute) }\end{array}$ & Uses & Characteristics \\
\hline \multicolumn{6}{|c|}{ 222-S Laboratory Complex-- } \\
\hline Type I & 1 & $1947 K 31$ & 1,867 & $\begin{array}{l}\text { Greenhouse } \\
\text { (operational } \\
\text { September } \\
1993 \text { ) }\end{array}$ & $\begin{array}{l}\text { HEPA filter } \\
99.95 \% \\
\text { efficiency at } \\
0.3 \text { micron }\end{array}$ \\
\hline
\end{tabular}

1 Type I units are authorized under the application for air space ventilation operations only. If the vacuum unit is to be used for any other purpose, the acceptable source term/emission estimates must be approved by the DOH before use of the unit for the planned activity.

\begin{tabular}{|c|c|c|c|c|c|}
\hline Unit & $\begin{array}{c}\text { Number } \\
\text { of } \\
\text { units }\end{array}$ & $\begin{array}{c}\text { Identification } \\
\text { number }\end{array}$ & $\begin{array}{l}\text { Flow rate } \\
\text { (cubic feet } \\
\text { per minute) }\end{array}$ & Uses & $\begin{array}{c}\text { Character- } \\
\text { istics }\end{array}$ \\
\hline
\end{tabular}

Mobile Sample Screening and Analys is Facilities--

\begin{tabular}{|c|c|c|c|c|c|}
\hline $\begin{array}{l}\text { Sampling } \\
\text { 1 aboratory-- } \\
\text { Type III }\end{array}$ & 7 & $\begin{array}{l}\text { 64-5189 (Trailer) } \\
64-4276 \text { (Trailer) } \\
64-4230 \text { (Trailer) } \\
64-4231 \text { (Trailer) } \\
64-4228 \text { (Trailer) } \\
68 B 4631 \text { (Truck) } \\
68 \mathrm{~B} 4626 \text { (Truck) }\end{array}$ & $\begin{array}{l}\text { Air flow } \\
\text { quantity } \\
\text { will satisfy } \\
\text { hood } \\
\text { containment } \\
\text { velocity of } \\
125 \text { feet per } \\
\text { minute } \\
\text { inward }\end{array}$ & $\begin{array}{l}\text { Provide work } \\
\text { space for } \\
\text { nonintrusive } \\
\text { media }\end{array}$ & $\begin{array}{l}\text { Chemical } \\
\text { hood with } \\
\text { HEPA filter } \\
\text { and } \\
\text { glovebox }\end{array}$ \\
\hline $\begin{array}{l}\text { Sample } \\
\text { preparation-- } \\
\text { Type II }\end{array}$ & 3 & $\begin{array}{l}\text { 64-4229 (Trailer) } \\
\text { 68B4625 (Truck) } \\
68 B 4630 \text { (Truck) }\end{array}$ & 50 & $\begin{array}{l}\text { Package } \\
\text { samples for } \\
\text { onsite or } \\
\text { offsite } \\
\text { analysis }\end{array}$ & $\begin{array}{l}\text { Glove box } \\
\text { to diminish } \\
\text { exposure to } \\
\text { personnel; } \\
\text { HEPA fi] ter } \\
\text { followed by } \\
\text { charcoal } \\
\text { absorbers. }\end{array}$ \\
\hline
\end{tabular}


DOE/RL-96-75, Rev. 0

$08 / 96$

\section{APPENDIX E}

EXAMPLE OF A LOG SHEET AND EXAMPLE CALCULATIONS TO DETERMINE MAXIMUM EXPECTED ANNUAL EMISSIONS 
DOE/RL-96-75, Rev. 0

$08 / 96$

This page intentionally left blank. 
EXANPLE:

LOG SHEET FOR TRACKING PORTABLE/TEMPORARY RADIOACTIVE AIRBORNE EMISSIONS UNITS FOR THE AREA OF THE HANFORD SITE

FOR UNIT NO.

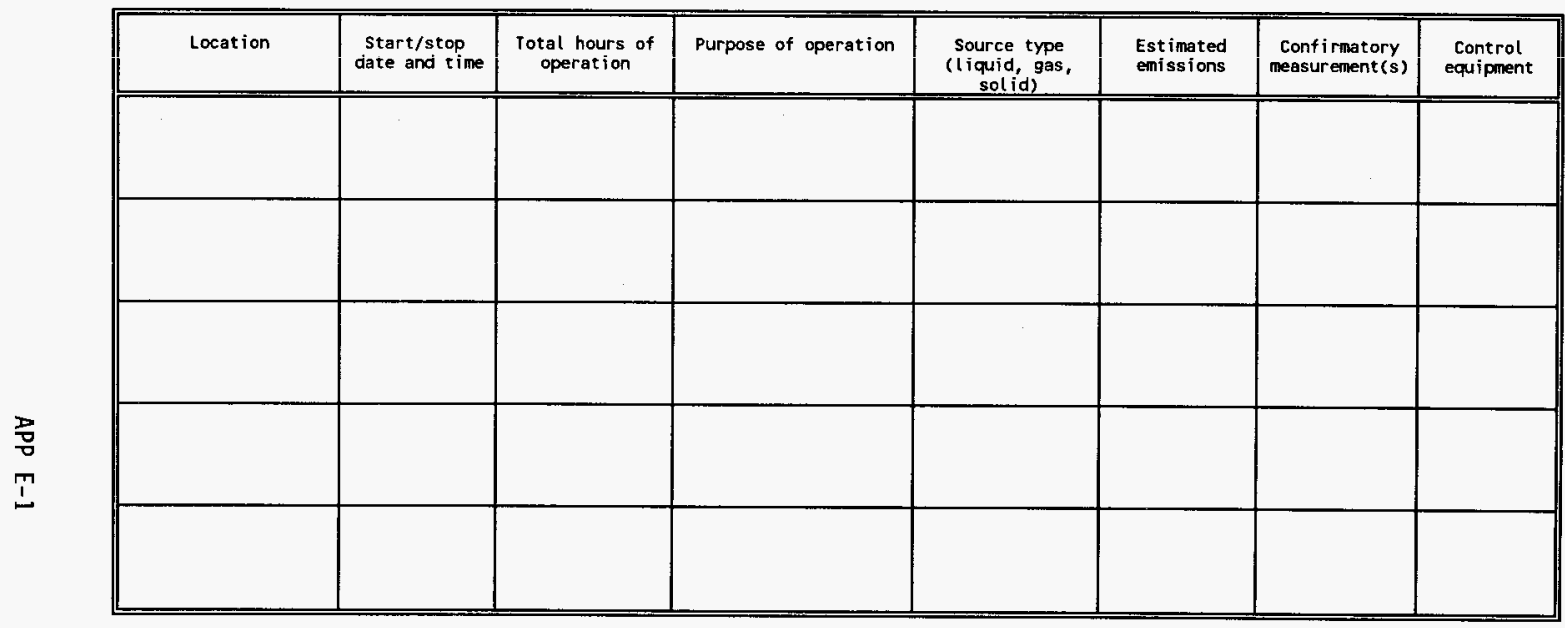

* Attach expected emissions calculations determined using the guidelines in the "Notice for Approval to Construct and Operate Portable/Temporary Radioactive Airborne Emissions Units" (DOE/RL-96-75) and also the actual emissions determined after use of the PTRAEU.

NOTE: This format is recommended for facility use. 


\section{MAXIMUM EXPECTED ANNUAL EMISSION CALCULATIONS}

The expected annual emissions from operations of PTRAEUs are depend on the number of PTRAEUs operating during the year and the flow rate, source inventory, and duration of the operation of each unit. This appendix outlines conservative annual emissions and dose rates possible for PTRAEUs. The total combined dose from all units of a particular type is presented for informational purposes only. Compliance use will be based on individual unit operations per activity. The total number of units will increase and decrease as needed to support the clean up efforts.

The PTRAEUs 1 isted in Appendix D were divided into the following three general unit types:

- Type I--Ventilation Filter System

- Type II--Mobile Sampling Preparation System

- Type III--Mobile Sampling Screening System.

Annual emissions and dose for the three types were based on RHLs. Type II and III calculations include a demonstration using sampling data from a site on the Hanford Site. The CAP 88 dose conversion factors were based on pub7 ished data (WHC 1991). 


\section{TYPE I PORTABLE/TEMPORARY RADIONUCLIDE AIRBORNE EMISSION UNIT CALCULATIONS}

\section{UNIT TYPE I--VENTILATION FILTERED SYSTEMS}

A Type I PTRAEU is a portable ventilation filter unit. These units are normally, but not limited to, an exhauster, vacuum, or other device that removes air from an area and draws the air through a HEPA filtration system attached to the unit or a greenhouse, or some other containment area.

\section{Assumptions:}

- There are 17 ventilation type PTRAEUs (Appendix A):

\begin{tabular}{llc}
\multicolumn{1}{c}{ Area } & & $\begin{array}{c}\text { Number of } \\
\text { PTRAEUs }\end{array}$ \\
\hline Operations & A11 areas & 4 \\
N Reactor & 100 Area & 1 \\
B Plant & 200 Area & 2 \\
300 Area & 300 Area & 4 \\
PUREX Facility & 200 Area & 5 \\
222-S Laboratory Complex & 200 Area & 1
\end{tabular}

TOTAL: $\quad 17$

- Assume 365 days per year of operation

- 40 CFR 61 Appendix D methodology was applied to the handling 1 imit. This methodology includes a factor of 0.001 to account for the physical state for particulate materials

- The radionuclide cesium-137 was used in the calculation primarily because of its prevalence throughout the Hanford Site. The RHLs are inversely proportional to the dose impact to the MEI; therefore, each radionuclide, at its RHL location (Area as listed by tables), would result in approximately the same offsite dose. Only one radionuclide was used in the calculations for the Type I PTRAEU to demonstrate the application of RHL and their use with this particular type of PTRAEU. If more than one radionuclide is present, the sum of the ratios of the total activity present to the RHL must be less than 1 , or the unit will not be able to operate under this application (Section 9.0). It is assumed, for the purpose of estimating annual potential release, that the one radionuclide used in the calculation (cesium-137) has a ratio equivalent to 1 . 
Radionuclide Radioactive Handling Limit 300 Area Table Ground Level
CAP 88 Dose Factor 300 Area Table Ground Level

Cs-137 5.7 E-01 Ci per day

4.77 E-01 mrem per year

- Possible offsite unabated dose from the operation of one PTRAEU:

$$
\begin{gathered}
\text { Cs-137: }\left(5.7 \times 10^{-01} \frac{\mathrm{Ci}}{\text { day }}\right)\left(365 \frac{\text { days }}{\text { year }}\right)\left(1 \times 10^{-03}\right) \\
\left(4.77 \times 10^{-1} \frac{\mathrm{mrem}}{\mathrm{Ci}}\right]=9.92 \times 10^{-02} \frac{\frac{\mathrm{mrem}}{\text { year }}}{\text { PTRAEU }} .
\end{gathered}
$$

- Possible offsite unabated dose for all 17 Type I PTRAEUs:

$$
\text { (17 PTRAEU) }\left[9.92 \times 10^{-02} \frac{\frac{\text { mrem }}{\text { year }}}{\text { PTRAEU }}\right]=2.67 \times 10^{+00} \frac{\mathrm{mrem}}{\text { year }} .
$$

- All remaining information regarding emissions and abated dose are found in Tables 1 through 5 of the NOC.

This is an example of calculating some of the information. All other information is self-explanatory according to the tables and information contained within.

\section{SUMMARY}

The annual unabated dose depends on the number of units operating, the duration of the operation and the source inventory. The approach to calculate expected annual unabated dose utilized very conservative assumptions. The assumptions were based on all listed units operating 365 days per year. In actual operations, all Type I PTRAEUs would not be operating for that duration. An additional conservatism built into this calculation is the Type I PTRAEUs will each handle the maximum allowable inventory each of the 365 days (assumed) of operation. Based on these two conservative factors, the actual annual unabated dose is expected to be much less than the calculated potential annual unabated dose. 


\section{TYPE II PORTABLE/TEMPORARY RADIONUCLIDE AIRBORNE EMISSION UNIT CALCULATIONS}

\section{UNIT TYPE II--MOBILE SAMPLING PREPARATION LABORATORIES}

The Mobile Sampling Preparation Laboratories are mounted on trucks and are used when conducting field sampling to provide worker safety and protection from the environment. These laboratories contain normal work space, plus areas to handle radioactive soil samples. Most handling activities consist of, but are not limited to, manipulating the samples for analysis through such activities as removing the sample from core barrels, homogenizing the material (mixing), and filling sample containers.

\section{Assumptions}

- Up to 100 samples per year will be analyzed in each Mobile Sampling Preparation Laboratory

- There are three Mobile Sampling Preparation Laboratories (Appendix A)

- Based on the calculations provided for a Type I PTRAEU, $9.92 \mathrm{E}-02$ is the potential maximum offsite unabated dose based on the RHL

- Annual potential offsite unabated dose for all Type II PTRAEUs is as follows:

$$
\text { (3 PTRAEU) }\left[9.92 \times 10^{-02} \frac{\frac{\text { mrem }}{\text { year }}}{\text { PTRAEU }}\right]=2.97 \times 10^{-01} \frac{\mathrm{mrem}}{\text { year }} .
$$

The following is a calculation of the annual potential unabated dose based on historical sampling data at a site on the Hanford Site:

- The number of samples are multiplied by the maximum Curies documented from total activity expected in a soil sample. Refer to Appendix $C$, Table C-2.

\begin{tabular}{lcccc} 
Nuclide & RHLs & & Sampl ing data & Dose factor \\
\cline { 4 - 5 } AM-241 & $1.0 \mathrm{E}-03$ & & $2.2 \mathrm{E}-05$ & $\frac{2.62 \mathrm{E}+02}{2.02}$ \\
CS-137 & $5.7 \mathrm{E}-01$ & $3.6 \mathrm{E}-02$ & $4.77 \mathrm{E}-01$ \\
Sr-90 & $3.1 \mathrm{E}-01$ & $6.6 \mathrm{E}-02$ & $8.72 \mathrm{E}-01$
\end{tabular}


- Determine the sum of the ratios for multiple radionuclides. If less than 1, determine annual potential unabated dose as follows:

$$
\begin{aligned}
& \text { An-241: }\left(100 \frac{\text { samples }}{\text { year }}\right)\left[2.2 \times 10^{-05} \frac{\mathrm{Ci}}{\text { sample }}\right]=2.2 \times 10^{-03} \frac{\mathrm{Ci}}{\text { year }} \\
& \text { Cs-137: }\left\{100 \frac{\text { samples }}{\text { year }}\right]\left[3.6 \times 10^{-02} \frac{C i}{\text { sample }}\right]=3.6 \frac{C i}{\text { year }} \\
& \text { Sr-90: }\left[100 \frac{\text { samples }}{\text { year }}\right]\left[6.6 \times 10^{-02} \frac{\mathrm{ci}}{\text { sample }}\right]=6.6 \frac{\mathrm{Ci}}{\text { year }} \\
& \sum \text { of the ratio: } \\
& \frac{\left(2.2 \times 10^{-3} \frac{\mathrm{Ci}}{\text { year }}\right)}{\left(1.0 \times 10^{-03} \frac{\mathrm{Ci}}{\text { day }}\right)\left(365 \frac{\text { day }}{\text { year }}\right)}+\frac{\left(3.6 \frac{\mathrm{Ci}}{\text { year }}\right)}{\left(5.7 \times 10^{-01} \frac{\mathrm{Ci}}{\text { day }}\right)\left[365 \frac{\text { days }}{\text { year }}\right)} \\
& +\frac{\left[6.6 \frac{\mathrm{Ci}}{\text { year }}\right]}{\left(3.1 \times 10^{-01} \frac{\mathrm{Ci}}{\text { day }}\right)\left(365 \frac{\text { day }}{\text { year }}\right)}=8.16 \times 10^{-02} .
\end{aligned}
$$

- Because the sum of the ratios is less than 1 , determine annual unabated dose as follows:

$$
\begin{gathered}
\text { Am-24l: }\left[100 \frac{\text { samples }}{\text { year }}\right]\left[2.2 \times 10^{-05} \frac{\mathrm{Ci}}{\text { sample }}\right]\left(1 \times 10^{-03}\right) \\
\left(2.62 \times 10^{+02} \frac{\mathrm{mrem}}{\mathrm{Ci}}\right]=5.76 \times 10^{-04} \frac{\mathrm{mrem}}{\text { year }} .
\end{gathered}
$$




$$
\begin{aligned}
& \text { CS-137: }\left[100 \frac{\text { samples }}{\text { year }}\right]\left[3.6 \times 10^{-02} \frac{\mathrm{Ci}}{\text { sample }}\right]\left(1 \times 10^{-03}\right) \\
& {\left[4.77 \times 10^{-01} \frac{\mathrm{mrem}}{\mathrm{Ci}}\right]=1.72 \times 10^{-03} \frac{\mathrm{mrem}}{\text { year }} \cdot} \\
& \text { Sr-90: }\left[100 \frac{\text { samples }}{\text { year }}\right]\left(6.6 \times 10^{-02} \frac{\mathrm{Cj}}{\mathrm{sample}}\right]\left(1 \times 10^{-03}\right) \\
& \left(8.72 \times 10^{-01} \frac{\mathrm{mrem}}{\mathrm{Cj}}\right)=5.76 \times 10^{-03} \frac{\mathrm{mrem}}{\text { year }} .
\end{aligned}
$$

- Annual potential offsite unabated dose from the operation of one Mobile Sampling Preparation Laboratory, using sampling data to determine annual potential dose.

$$
\begin{aligned}
\left(5.76 \times 10^{-04} \frac{\mathrm{mrem}}{\text { year }}\right) & +\left[1.72 \times 10^{-03} \frac{\mathrm{mrem}}{\text { year }}\right]+\left[5.76 \times 10^{-03} \frac{\mathrm{mrem}}{\text { year }}\right) \\
& =8.06 \times 10^{-03} \frac{\mathrm{mrem}}{\text { year }} .
\end{aligned}
$$

- Annual potential offsite unabated dose for all three Mobile Sampling Preparation Laboratories is as follows:

$$
\text { (3PTRAEUs) }\left(8.06 \times 10^{-03} \frac{\frac{\text { mrem }}{\text { year }}}{\text { PTRAEU }}\right)=2.41 \times 10^{-02} \frac{\mathrm{mrem}}{\text { year }} .
$$

12

- Al1 remaining information regarding emissions and abated dose are found in the NOC application Tables 1 through 5 . This is an example of calculating some of the information. All other information is self-explanatory according to the tables and information contained within. 


\section{SUMMARY}

2

The annual unabated dose depends on the number of units operating, the duration of the operation, and the source inventory. The approach to calculate expected annual unabated dose used very conservative assumptions. The assumptions were based on all 1isted units operating 365 days per year. In actual operations, all Type II PTRAEUs would not be operating for that duration. An additional conservatism built into this calculations is the Type II PTRAEUs will each handle the maximum allowable inventory each of the 365 days (assumed) of operation. Based on these two conservative factors, the actual annual unabated dose is expected to be much less than the calculated potential annual unabated dose. 
3

TYPE III PORTABLE/TEMPORARY RADIONUCLIDE AIRBORNE EMISSION UNIT CALCULATIONS

\section{UNIT TYPE III--MOBILE SAMPLING SCREENING LABORATORIES}

The Mobile Sampling Screening Laboratory is used when conducting field sampling to provide worker safety and protection from the environment.

\section{Assumptions}

- Up to 1,100 samples per year will be analyzed in the Mobile Sampling Screening Laboratory

- There are seven Mobile Sampling Screening Laboratories (Appendix A)

- Based on the calculations provided for a Type I PTRAEU, $9.92 \mathrm{E}-02$ is the potential maximum offsite unabated dose based on the RHL

- Annuar potential offsite unabated dose for all Type III PTRAEUs is as follows.

$$
\text { (7 PTRAEU) }\left[9.92 \times 10^{-02} \frac{\frac{\text { mrem }}{\text { year }}}{\text { PTRAEU }}\right]=6.94 \times 10^{-01} \frac{\mathrm{mrem}}{\text { year }} \text {. }
$$

23

24

25

26

27

28

29

30

31

32

33

34

35

36
The following is a calculation of the annual potential unabated dose based on historical sampling data at a site on the Hanford Site.

- The number of samples are multiplied by the maximum Curies documented from total activity expected in a soil sample. Refer to Appendix $C$, Table C-2.

$\begin{array}{llll}\text { Nuclide } & \frac{\text { RHLs }}{1.0} E-03 & \frac{\text { Sampling Data }}{2.2} \text { E-05 } & \text { Dose Factor } \\ \text { Am-2.41 } & 1.7 \mathrm{E}-01 & 3.6 \mathrm{E}-02 & 2.62 \mathrm{E}+02 \\ \mathrm{Cs}-1.37 & 5.7 \mathrm{E}-01 & 6.6 \mathrm{E}-02 & 4.77 \mathrm{E}-01 \\ \mathrm{Sr}-90 & 3.1 \mathrm{E}-01 & 8.72 \mathrm{E}-01\end{array}$


- Determine the sum of the ratios for multiple radionuclides; if less than 1 determine annual potential unabated dose as follows:

$$
\begin{aligned}
& \text { Am-241: }\left(1100 \frac{\text { samples }}{\text { year }}\right]\left[2.2 \times 10^{-05} \frac{\mathrm{Ci}}{\text { sample }}\right]=2.42 \times 10^{-02} \frac{\mathrm{Ci}}{\text { year }} \\
& \text { Cs-137: (1100samples) }\left[3.6 \times 10^{-02} \frac{\mathrm{Ci}}{\text { sample }}\right]=3.96 \times 10^{+01} \frac{\mathrm{Ci}}{\text { year }} \\
& \text { Sr-90: }\left[1100 \frac{\text { samples }}{\text { year }}\right]\left[6.6 \times 10^{-02} \frac{\mathrm{Ci}}{\text { sample }}\right]=7.26 \times 10^{\text {t01 }} \frac{\mathrm{Ci}}{\text { year }} \\
& \sum \text { of the ratio: } \\
& \frac{\left(2.42 \times 10^{-02} \frac{\mathrm{Ci}}{\text { year }}\right]}{\left(1.0 \times 10^{-03} \frac{\mathrm{Ci}}{\text { day }}\right)\left[365 \frac{\text { day }}{\text { year }}\right]}+\frac{\left(3.96 \times 10^{-01} \frac{\mathrm{Ci}}{\text { year }}\right)}{\left(5.7 \times 10^{+01} \frac{\mathrm{Ci}}{\text { day }}\right)\left[365 \frac{\text { days }}{\text { year }}\right)} \\
& +\frac{\left[7.26 \times 10^{+01} \frac{\mathrm{Ci}}{\text { year }}\right]}{\left(3.1 \times 10^{-01} \frac{\mathrm{Ci}}{\text { day }}\right)\left(365 \frac{\text { day }}{\text { year }}\right)}=8.98 \times 10^{-01} .
\end{aligned}
$$

- Because the sum of the ratios is less than 1 , determine annual unabated dose as follows:

$$
\begin{gathered}
\text { Am-241: }\left(1100 \frac{\text { samples }}{\text { year }}\right]\left(2.2 \times 10^{-05} \frac{\mathrm{Ci}}{\text { sample }}\right)\left(1 \times 10^{-03}\right) \\
\left(2.62 \times 10^{+02 \frac{\mathrm{mrem}}{\mathrm{Ci}}}\right)=6.34 \times 10^{-03} \frac{\mathrm{mrem}}{\text { year }} .
\end{gathered}
$$




$$
\begin{gathered}
\text { Cs-137: }\left[1100 \frac{\text { samples }}{\text { year }}\right]\left(3.6 \times 10^{-02} \frac{\mathrm{Ci}}{\text { sample }}\right]\left(1 \times 10^{-03}\right) \\
{\left[4.77 \times 10^{-01 \frac{\mathrm{mrem}}{\mathrm{Ci}}}\right]=1.89 \times 10^{-02} \frac{\mathrm{mrem}}{\text { year }} \cdot} \\
\text { Sr-90: }\left[1100 \frac{\text { samples }}{\text { year }}\right]\left[6.6 \times 10^{-02} \frac{\mathrm{Ci}}{\mathrm{sample}}\right]\left(1 \times 10^{-03}\right) \\
\left(8.72 \times 10^{-01 \frac{\mathrm{mrem}}{\mathrm{Ci}}}\right)=6.33 \times 10^{-02} \frac{\mathrm{mrem}}{\text { year }} .
\end{gathered}
$$

$$
\begin{aligned}
{\left[6.34 \times 10^{-03} \frac{\mathrm{mrem}}{\text { year }}\right] } & +\left[1.89 \times 10^{-02} \frac{\mathrm{mrem}}{\text { year }}\right]+\left[6.33 \times 10^{-02} \frac{\mathrm{mrem}}{\text { year }}\right] \\
& =8.85 \times 10^{-02} \frac{\mathrm{mrem}}{\text { year }}
\end{aligned}
$$

6

7

8

- Annual potential offsite unabated dose from the operation of one Mobile Sampling Screening Laboratory, using sampling data to determine annual potential dose is as follows:

- Annual potential offsite unabated dose for all Mobile Sampling Screening Laboratories is as follows:

$$
\text { (7PTRAEUs) }\left[8.85 \times 10^{-02} \frac{\frac{\text { mrem }}{\text { year }}}{\text { PTRAEU }}\right]=6.19 \times 10^{-01} \frac{\mathrm{mrem}}{\text { year }} \text {. }
$$

11

12

13

14

15

16

17

18

19

20

$? 1$

\section{SUMMARY}

The annual unabated dose depends on the number of units operating, the duration of the operation, and the source inventory. The approach to calculate expected annual unabated dose used very conservative assumptions. The assumptions were based on all listed units operating 365 days per year. In actual operations, all Type III PTRAEUs would not be operating for that duration. An additional conservatism built into this calculations is the Type III PTRAEUs will each handle the maximum allowable inventory each of the 365 days (assumed) of operation. Based on these two conservative factors, the 
DOE/RL-96-75, Rev. 0

$08 / 96$

1 actual annual unabated dose is expected to be much less than the calculated 2 annual potential unabated dose.

3 


\section{DISTRIBUTION}

OFFSITE

ONSITE
A. W. Conklin, Head

Air Emissions and Defense Waste Section Division of Radiation Protection

State of Washington Department of Health

Airdustrial Park Building 5, LE-13

01 ympia, Washington 98504-0095

J. Wilkinson

Confederated Tribes of the Umatilla

Indian Reservation

P. 0. Box 638

Pendleton, Oregon 97801

D. Powaukee

Nez Perce Tribe

P. 0. Box 305

Lapwai, Idaho 80540

R. Jim, Manager

Environmental Restoration/

Waste Management Program

Confederated Tribes and Bands of the Yakama Nation

P. 0. Box 151

Toppenish, Washington 98948

U.S. Department of Energy,

Richland Operations office

MSIN

C. M. Bell

R. M. Carosino

J. E. Rasmussen

H. M. Rodriguez (6)

Reading Room (2)

)

A5-52

A4-52

A5-15

A5- 15

$\mathrm{H} 2-53$

Bechtel Hanford. Inc.

E. T. Coenenberg

H9-11

J. T. Hadley

H9-11

J. P. Zoric

$\times 5-57$

Boeing Computer Services

D. J. Farquhar

Al-05

ICF Kaiser Hanford

B. J. Dixon

B4-20 


\section{DISTRIBUTION (cont)}

MSIN

Pacific Northwest National Laboratory

Hanford Technical Library

KI-11

Westinghouse Hanford Company

J. M. Barnett

T4-08

J. A. Bates

H6-36

R. J. Boom

T6-12

H. C. Boynton

T4-02

J. F. Brown

S5-03

M. D. Campbe 11

H6-26

W. E. Davis

H6-2O

J. L. Demarest

G1 -40

L. P. Diediker

H6-36

T. A. Dillhoff

N2-57

W. T. Dixon

H6-21

D. L. Flyckt

S6-71

D. W. Fritz

H6-36

C. K. Girres

T3-28

B. P. Gleckler

H6-36

E. M. Greager

H6-36

$P$. R. Gunter

S5-07

M. J. Hall

T6-12

D. L. Johnson

S5-66

M. J. Hall

T6-12

S. E. Killoy

S4-66

J. M. Kisielnicki

L6-39

G. L. LeBaron

S6-19

J. J. Luke

H6-25

C. E. Marple

S4-56

D. J. McBride

T5-54

K. M. McDonald

T4-03

S. E. Myers

S3-24

A. D. Poor

L6-55

D. E. Rasmussen

$\mathrm{N} 1-47$

J. R. Robertson

H6-21

R. W. Szelmeczka

L6-05

K. S. Tollefson

57-01

E. F. Votaw

GI -13

D. J. Watson

$X 3-79$

Air Operating Permit File

$\mathrm{H} 6-25$

DPC

A3-94

EDMC (2)

H6-OB 